\title{
Match of Inputs and Outputs of Higher Education to Local Market in Mafraq Governorate: Perceived Students' Performance Affect by Geographical Location
}

\author{
Waleed Al-Awawdeh ${ }^{1}$, Salem Al-Oun ${ }^{1} \&$ Khalaf Al-Oun ${ }^{2}$ \\ ${ }^{1}$ Faculty of Economics and Administrative Sciences, Al Al-Bayt University, Mafraq, Jordan \\ ${ }^{2}$ Arab Open University, Amman, Jordan \\ Correspondence: Salem Al-Oun, Faculty of Economics and Administrative Sciences, Al Al-Bayt University, PO \\ Box 130040, Mafraq 25113, Jordan. E-mail: brdp_salim@yahoo.com
}

Received: December 12, 2011

Accepted: February 25, 2012

Published: May 1, 2012

doi:10.5539/ijbm.v7n9p175

URL: http://dx.doi.org/10.5539/ijbm.v7n9p175

\begin{abstract}
The relationship between human capital and economic growth is highly acclimatized by the quality and distribution of education in the labor force. However, to realize this issue it is important to focus on the base of education at the school level. There is evidence that environmental positions affect students' performance. The study was conducted using field research. Interviews and surveys were conducted with 229 administers located at three directorates of the North Badia region. Subjects were selected using stratified random sampling. Results indicated that education at Mafraq Governorate lacks quality and quantity of supply as it is located away from urban centers. Over all perceived performance was affected differently in the three directorates of North Badia; the highest perceived performance was in Central Mafraq and the least in Northeast Badia. Geographical location is associated with: number of students at Third, Fourth, Fifth, Sixth, Seventh, and Ninth Elementary grades; number of students at Eleventh Grade Literature, Computer, Nursing stream, and number of sections at Eleventh grade Scientific, Literature, Computer, and Vocational streams; and with number of Physics and Athletics teachers. It is negatively associated with number of students at Twelfth grade scientific stream. There should be emphasis of joining schools together.
\end{abstract}

Keywords: geographical location, student's performance, higher education, market, Mafraq, Jordan

\section{Introduction}

Human capital is considered an important factor for economic growth and is effective in reducing poverty (The World Bank, 2011). The relationship between human capital and economic growth is highly acclimatized by the quality and distribution of education in the labor force. It is necessary to adopt policies that lead to the creation of diversified and competitive sectors capable of absorbing the more educated labor force to transform human capital into higher economic growth. Investing in better-distributed education in the labor force could lead to higher productivity. Middle East has dedicated substantial resources over the last 40 years to improve the education systems (Galal, 2008). Most children benefit from compulsory schooling. Most countries of the Middle East were able to achieve gender equality at almost all levels of education (Galal, 2008). The average number of years of schooling in Middle East countries is below East Asia and Latin America regions by more than one year. However, the rapid expansion of secondary and higher education was accommodated by employment in the public sector at relatively high wages rather than by demand for educated labor by the private sector. In addition, public expenditure is biased in favor of students at higher levels of education in favor of the socially privileged class. Education does not appear to have contributed to the low poverty levels of the region. Jordan poverty rates fell despite low economic growth in the 1990s (Galal, 2008).

In Jordan, the Ministry of Higher Education gave the higher education sector its attention during the last two decades as its perceived role in the comprehensive development of other sectors. The development of higher education sector focused on content, programs, and pedagogy that control quality and quantity. It focused on international standards that provide competitiveness of graduates at the regional and international levels. Seven cores of focus were adapted that included: university management; admission procedures and equal opportunities; 
accreditation and quality assurance; scientific research, development and graduate studies; IT and technology skills; funding; and learning environment. To match these goals, the Ministry of Education was accredited the ISO9001 for Management and Quality Assurance in its educational and other activities that targeting the development of human resources (teachers and students) at the school level (MoHE, 2007).

How such development plans can be adopted by local communities that are the most in need for socio-economic sustainable development like those at the Governorate of Mafraq. Such vital development includes the simplest executive jobs to the most complex management ones required.

\subsection{Significance and Goals of the Study}

Evaluation and assessment as initiatives for higher education development in Badia Region are considered to be a central core for quality assurance. The main shortcoming of past efforts lies in the weak link between the improvements in the level, quality, and distribution of human capital and economic growth, income distribution, and poverty reduction. This is further reinforced by the lack of readiness of most education systems in the North Badia Region to deal with globalization and the increasing emphasis on knowledge in the development process, enormous youth swell, and the additional financial resources required expanding higher levels of instruction. However, to realize the importance of such vision it is important to focus on the base of education at the school level. North Badia Regions has produced fewer educational outcomes than many competitors, as measured by years of educational attainment in the adult population. The educational achievements are compromised in part by high dropout rates, by relatively low scores on national tests, and by the production of more graduates in humanities than in science. For example, the North Northwest Badia North Badia Regions high school graduates are as follows: Vocational (0), Judicial (0), Information Management (0), Scientific (59), Literature (984). Meanwhile, the high school graduates of Mafraq center: Vocational (275), Judicial (0), Information Management (0), Scientific (451), Literature (1163) (Department of Statistics, 2004). Applied science majors are not established in schools within the dispersed human settlements from the major urban center, Mafraq City. The further settlements are from the capital city Amman, the less such majors are offered to local communities. Whilst, such majors qualify high school students to be accepted to applied science majors at the university level such as agriculture, arid land development, resources management, engineering, architecture, nursery, and medicine that are believed to be the most needed by the local market in Mafraq Governerate. Further, lack of specialized teachers of the various majors in the Northwest Badia Region. The graduate of bachelor from the different universities who are available in the area are as follows: Physics (39), Chemistry (30), Biology (25), Math (110), IT (40), Agriculture (4), Nursing (0). This can be interpreted when we look at the numbers of high school graduates in the different fields (Department of Statistics, 2004).

Being the first of its kind, this study emphasizes the role of human resources development at the educational institutions in providing qualitative and competitive graduates to Mafraq market. Such investment can enhance socio-economic security for the local community. This research is significant by being a model that focuses on local education development within socio-cultural and economic constraints to sustain resources independently from central governmental support. The researchers are expected to gain more expertise in the development and evaluation of, educational systems, pedagogy, and its relation to market needs.

Goals of the study are to diagnosing the relevance of inputs and outputs of higher education that will make Mafraq Governorate dependent on its own human resources, especially that the Governorate is launching multiple industrial zones. The study outcomes will provide a set of guidelines towards making educational environments more efficient. The outcomes are expected to draft guidelines towards a strategy to restructure higher education inputs in Mafraq Governorate in order to supply demands of the local market.

\section{Literature Review and Theory}

\subsection{Marketing Higher Education}

Laclau and Mouffe's (1985) logics of equivalence and difference in the formation of social relations and alternative discourses provided key theoretical concepts in the study of the marketing of higher education. The study showed how sponsored degrees extend the promise of successful careers and create antagonistic subject positions such as those between graduates and non-graduates. It showed that hybridization of tradition and market relevance discourses transforms higher education through multiple subject positions. Accommodating curricula designed for industry, validate knowledge from a traditional subject position, but it could not avoid entering a subject position framed and validated by market relevance (Lowrie and Willmott, 2006).

A number of authors have recognized the increasingly important role that marketing is playing in higher education institutions' efforts to attract new students (Carlson, 1992; Fisk and Allen, 1993; Murphy and 
McGarritty, 1978; Wonders and Gyuere, 1991). Marketing actually is linked to needs assessment, market analysis, product development, pricing, or distribution (Kotler and Fox, 1995; Murphy and McGarrity, 1978). The common feature of all marketing definitions is the statisfaction of customer needs (Conway, MacKay and Yorke, 1994; Robinson and Long, 1987; Scott, 1999; Wallace, 1999). When universities offer qualifications that satisfy student needs, marketing mix suggested to a set of controllable variables that an institution may use to produce the response it wants from its various publics through a 4Ps analysis (Product, Price, Place, and Promotion) (Kotler and Fox, 1995). Price relates to aspects such as the tuition fees, bursaries and scholarships, and payment terms for tuition fees. Place is the distribution method; face-to-face or distance learning. Promotion is comprised of a package of tools such as advertising, public relations, and face-to-face selling that could take place at an open day. With the intangible nature of the services, some call for a additional elements to be added: people (Coleman, 1994; Gray, 1991; Keller, 1983; Lin, 1999) and physical facilities (Kotler and Fox, 1995).

\subsubsection{Challenges Facing Education Sector}

The conditions under which education systems contribute to economic and social development have changed. Several new challenges are introduced: (1) Globalization increased the importance of knowledge in the development process; (2) Clients who are served by the education system changed; (3) The number of eligible students seeking post-compulsory education increased considerably over the next decades; (4) The education systems needed to become more effective in transmitting skills and competency; (5) Facing such challenges increased costs (Galal, 2008).

\subsubsection{Challenges Facing the Education Sector in Jordan}

Globalization and Knowledge Economy: Jordan possesses education systems that exhibit better engineering, more aligned incentives, and greater public accountability than some countries in the region. Jordan's education system is one of the region's most flexible in Vocational Education and Training (VET). The contribution of education and human resources to the overall index is significant in Jordan. However, the individual needs of students are not commonly addressed in the classroom; there is little consideration of individual differences in the teaching-learning process. Current pedagogical practices lack support for weak students, although Jordan appears to be making additional investments in this area. In 2000, the Jordanian Higher Education Accreditation Council was established along with methods to conduct internal and external evaluation of university programs. (Galal, 2008).

Education Finance: Jordan allocates less than 15 percent of its budget to education. In the 1980s, Jordan constructed science labs and libraries in rented and government-owned facilities to improve the teaching of science. In the late 1980s, Jordan introduced information system to improve decision making at the central and governorate levels. In Jordan, services were contracted out to the private sector since 2000 (e.g., development of curricula and pedagogical tools, teacher trainings, and installation of ICT equipment) (Galal, 2008).

Enrollement: Jordan is more successful in providing equitable access and higher-quality education to its population than other countries. Over the period 1970-2003, Jordan was relatively more successful in providing access to reasonable-quality education for most of their populations than were the rest of the countries in the region. Jordan currently has average Net Enrollment Rate (NER) above 90 percent. Jordan experienced temporary setbacks in enrollment rates before recovering and continuing their paths of growth in 1995. As for secondary education, Gross Enrollment Rate (GER) it reached 85 percent or more. By 1990, Jordan had surpassed the benchmark of the average higher education for the region, which has quintupled from 5 percent in 1970 to 24 percent. Jordan constitutions also guarantee the right of education for all, but the state did not make education for free. Jordan increasingly relied on households to contribute to the cost of higher education by paying fees, and encouraged private provision of education, especially at the tertiary level (Galal, 2008).

Gender: Gender equality was reached before full primary enrollment; female students outnumber male students by a significant margin. Jordan has the most equal education distribution in the region (Galal, 2008).

Education and Migration: Among the 195 countries, Jordan is among the top 30 countries with the proportion of skilled emigrants in the total emigration stock, and is ranked 27 (Docquier and Marfouk, 2004). Migration is important for resolving local market imbalances with benefits to individuals and nations involved. Labor movement is important for the MENA because of excess labor in Jordan and excess capital in neighbouring countries such as the Gulf Co-operation Council Countries (The World Bank, 2011). Jordan export workers to the Gulf, but also imports uneducated workers from neighboring countries like Egypt and Syria. Nationals are given skilled jobs at higher wages. Asian workers are increasingly given unskilled jobs at lower wages and at wages below those of workers from Arab countries (Girgis, 2002). The rates of return to education in Jordan are low and declining (The World Bank, 2011). 
Social Challenges and Market Demands: Students and parents increasingly favor professional degree programs that help graduates to get a job rather than a liberal education that enriches their lives. Society directs universities that the cost of education is more important than educational quality. At the same time, the labor market seeks low-cost quality services rather than prestige ones. This could be because a culture of excellence is no longer acceptable or sustained by the public. Although this shift from prestige-driven to cost-competitive market forces may broaden, the mission and capacity of many universities could be at the expense of the excellence of the best educational institutions (Duderstadt, 1999). Excessive attractiveness of some study programs causes not only disproportion in the market for specialists, but also compromise it (Valiulis and Zavadskas, 1999; Valiulis, 2003).

\subsection{Incentives and Accountability in Supply and Demand}

Arab coutries tended to focus on engineering education more than on incentives on supply and demand (Galal, 2008).

Aligning incentives on the supply side: On-going reforms require improving supply quality at the school level as follows: (1) Aligning the incentives of teachers, bureaucrats, and private sector education providers to produce good quality education. In public schools it requires: motivating teachers to teach effectively in the classroom through performance based financial and pecuniary rewards, improving training of teachers, and decentralization and the engagement of parents in the activities of the school and the selection of teachers. In addition, it involves: (a) greater competition by allowing students to enroll in the school of their choice on the basis of systematic information prepared by the Ministry of Education; (b) fair competition and the availability of accurate information about school performance; (c) retainment of its authority to verify equal access and a minimum curriculum for all students; and (d) resolvement of disputes between schools and parents to fulfill the role of an authority based on previously known rules, procedures, and penalties. (2) Improving the physical quality of schools, and upgrading of the curriculum by increasing pressure on the treasury to spend sufficiently on buildings and their maintainance and by delivering services (Galal, 2002).

Aligning incentives on the demand side: Education is an investment and its reform has to be seen as part of a larger reform process of the entire economy (Panizza, 2001). The proposed reforms to encourage labor-intensive growth measures to rationalize the prices of capital relative to labor (Radwan, 1998; Fawzy, 2002). It is important that additional reforms to be undertaken to shift demand for labor from the government to the private sector (Assaad, 1994).

\subsection{Quality of Teaching/Learning Environment}

Educational environment is the setting where interaction between students and teachers takes place. There is evidence that environmental positions and personality characteristics and attitude of students and teachers towards school affect students' performance (Brooks and Rebeta, 1991; Gump, 1987; Weinstein, 1985; Gump, 1987; Weinstein, 1985; Totusek and Staton-Spicer, 1982; Koneya, 1976; Lewin, 1943). Basic physical requirements of the school building like minimum standards for classroom size, acoustics, lighting, heating and air conditioning, in addition to pedagogical, psychological and social variables as a whole shape the context within which learning takes place (Lackney, 1999) as follows:

\subsubsection{Teaching Environment}

A study by Tam and Cheng (1995) measured the internal social environment of the school organization and its relations to performance of teachers and students. Factors that reflect the teaching environment include: strength of leadership, staff frustration, positive classroom climate, caring and support to students (a combination of three environment variables: esprit, intimacy, and student-centeredness), formalization, and pupil control (pupil control ideology minus organizational ideology) (Ming, 1994; Ming and Cheong, 1995). Leadership factor was measured by the integration of the five aspects: instructional (educational), structural (hierarchy of authority, hindrance (difficulty and obstruction) as signs of bureaucratization of a school, and participative decision), human resource, political, and cultural (symbolic) (Sergiovanni, (1984; Bush, 1986; Bolman and Deal, 1991; Cheng, 1993). A minimum period of time required for leadership to take root (Ming and Cheong, 1995; Cheng, 1993). Personal characteristics of students include age and gender. Personal characteristics of teachers include average teaching experience (teaching age), age of the teacher, and gender of the teacher. Teacher performance was measured by efficacy and time-use at the individual level. Students' performance was measured by learning efficacy (efficiency). Students' competition was a function of affiliation and involvement; better social relationship among students increase students' engagement in studying (Ming, 1994; Ming and Cheong, 1995). 


\subsubsection{School Environment}

Schools Size: Small schools benefit students socially and academically and serve as true community centers. The use of school facilities can be shared with a variety of community organizations fostering meaningful partnerships civic participation and engagement, as well as opportunities for children to walk and bike (Lackney, 1999). On average, the research indicates that an effective size for an elementary school is in the range of 300-400 students and that 400-800 students is appropriate for a secondary school (7-8) (Cotton, 1996). School size affects the following:

- $\quad$ Academic Achievement: Some research finds no difference between achievement levels of students in large and small schools, including small alternative schools (Burke, 1987; Haller, Monk, and Tien, 1993; Stockard and Mayberry, 1992; Walberg, 1992). Others find student achievement in small schools to be superior to that in large schools (Bates, 1993; Eberts, Kehoe, and Stone, 1982; Eichenstein, 1994). Smaller elementary schools particularly benefit ethnic minority and low socioeconomic status students' achievement (Summers and Wolfe, 1977; Fowler, 1992; Eberts, Kehoe, and Stone, 1982; Stockard and Mayberry, 1992). Achievement measures include: school grades, test scores, honor roll membership, subject-area achievement, and assessment of higher-order thinking skills.

- $\quad$ Quality of the Curriculum and Cost-Effectiveness: Howley $(1994,1996)$ revealed that there is no reliable relationship between school size and curriculum quality. In terms of instructional approaches and strategies, teachers in small schools are more likely to form teaching teams, integrate their subject matter content, employ grouping and cooperative learning, and use alternative assessments (Raze, 1985; Rutter, 1988; Walberg, 1992). The relationship between size and costs varies depending on school circumstances (Robertson, 1995; Rogers 1987).

- $\quad$ Student Attitudes: Studies by Aptekar (1983) and Bates (1993) indicated that student attitudes overwhelmingly favor small schools over large ones.

- $\quad$ Social Behavior: Studies by Duke and Perry (1978); Gottfredson (1985); Stockard and Mayberry (1992) showed that small schools have lower incidences of negative social behavior than do large schools. Further, Garbarino (1980) indicated that small schools have lower incidence of crime levels and less serious student misconduct.

- $\quad$ Extracurricular Participation: Small schools (100-150), in comparison with large schools (over 2,000) offer students greater opportunities to participate in extracurricular activities (Barker and Gump, 1964; Burke, 1987; Cawelti, 1993; Howley, 1996). Participation in school activities, student satisfaction, number of classes taken, community employment, and participation in social organizations were superior in small schools than large schools (Barker and Gump, 1964; Schoggen and Schoggen, 1988). Students in small schools come to know and care about one another to a much greater degree than is possible in large schools (Berlin and Cienkus, 1989; Rutter, 1988; Schoggen and\& Schoggen, 1988; Berlin and Cienkus, 1989; Rutter, 1988; Stockard and Mayberry, 1992; Burke, 1987; Walberg, 1992).

- $\quad$ Attendance: Students in smaller schools have higher attendance rates than those in large schools (Fowler, 1995; Gregory, 1992; Gregory and Smith, 1987; Howley, 1994; Smith and DeYoung, 1988; Walberg, 1992). Also students who change from large schools to small secondary schools generally exhibit improvements in attendance (Bates, 1993; McGanney, Mei, and Rosenblum, 1989; Rutter, 1988).

- $\quad$ Dropouts: Measured either as dropout rate or graduation rate, the holding power of small schools is considerably greater than that of large schools (Fetler, 1989; Gregory, 1992; Pittman and Haughwout, 1987; Rogers, 1987; Smith and DeYoung, 1988; Stockard and Mayberry, 1992; Toenjes, 1989; Walberg, 1992).

- $\quad$ Belongingness/Alienation: Studies found a greater sense of belonging (expressed as a lower level of alienation) among students in small schools than in large ones (Burke, 1987; Campbell et al., 1981; Fowler and Walberg, 1991; Gregory, 1992; Howley, 1994; Pittman and Haughwout, 1987; Stolp, 1995; Walberg, 1992).

- $\quad$ Self-Concept: Grabe (1981), Rutter (1988), and Stockard and Mayberry (1992) found that personal and academic self-regard are more positive in smaller schools.

- Interpersonal Relations: There are positive correlations between small schools and favorable interpersonal relations among students and between students and teachers, especially teacher attention and caring (Bates, 1993; Burke, 1987; Fowler and Walberg, 1991; Gottfredson, 1985; Gregory and Smith, 1982; 1983; Smith, Gregory, and Pugh, 1981; Kershaw and Blank, 1993; Pittman and Haughwout, 1987; Rutter, 1988; Smith and DeYoung, 1988; Stockard and Mayberry, 1992). 
- Teacher Attitudes: administrator's and teacher's attitudes toward work, administration, and one another, as well as the incidence of cooperation with their colleagues are in favor to smaller schools (Eberts, Kehoe, and Stone, 1982; Gottfredson, 1985; Gregory, 1992; Johnson, 1990; Stockard and Mayberry, 1992).

- $\quad$ College Variables: college readiness and the merits of college-related variables such as entrance examination scores, acceptance rates, attendance, grade point average, and completion found small schools equal (Fowler, 1992; Jewell, 1989) or superior (Burke, 1987; Swanson, 1988) to large ones.

\subsection{Research Setting Demographics}

Mafraq Governorate area is about 26435 Square kilometers, which represents about $29.6 \%$ out of Jordan's total area, and the second largest governorate after Ma'an. Mafraq Governorate population reached 239,000 and represents about $4.6 \%$ of Jordan's total population of 2001, of which $47.6 \%$ are females and $52.4 \%$ of which are males; $42 \%$ are less than 15 years old compared to Jordan's rate, which is $39 \%$; and $33.1 \%$ urbanite and $66.9 \%$ town residents. Population density is about 9-11 per one square kilometers compared to the rest of Jordan, which is 58 per square kilometer. Life expectancy is 65.6 years old for females and 70 years old for males, compared to 68.6 years old Jordan's females and 71.1 years Jordan's males. Average infant death for each on thousand of a year old is $43 \%$ males and $31 \%$ females compared to rates of $30.7 \%$ males and $29.3 \%$ females in Jordan. Average family size is $6.4 \%$ compared to $5.8 \%$ of Jordan's. Poverty level is $28 \%$ compared to $11 \%$ for Jordan. Crime rate is $2.7 \%$ of Jordan's total. About 2890 students in 41 elementary schools benefit from the feeding program established by the Ministry of Education. Car ownership is $1 / 30$ compared to $1 / 17$ in the rest of Jordan (Department of Statistics, 2002).

Economic activities in Mafraq governorate reached $36.8 \%$ compared to $38.8 \%$ in Jordan. Unemployment reached $17.3 \%$ compared to $14.7 \%$ in Jordan in 2001. Incomes of less than $100 \mathrm{JD}$ represented $20 \%$ and 100-199JD represented 62\% and 200-299JD 14\%. About $0.9 \%$ of total registered Jordan's engineers were from Mafraq Governorate in 2000. Registered lawyers represented 1.8\% from Jordan's total in 2000. Those who are registered are 264 and of which 1818 were employed, statistics of 1999-2002, the registered were 44 and the employed are 24. The department of employment issued 6837 approval for foreigners. No vocational centers ate the governorate. Those who benefited from training programs at the Work Affairs Ministry in 2000 were no females, and 18/20 who applied and employments were in two institutions. Of those who applied in this program about 3.3\% were employed out of Jordan's total. About $2.7 \%$ of total applicants to the Civil Services Court were from Mafraq Governorate in 2001. Those who applied to Public Services court were employed. Manpower reached 13433 paid and unpaid, which is about $2.3 \%$ of Jordan's rate, $28 \%$ are females and $6 \%$ are foreigners. $69 \%$ of those work in public sectors and $14 \%$ for their own in 1999. Manpower for 2001 rated $4 \%$ of the total Jordan's manpower. In 2001 manpower rated 52\% in defense and management of education and health, meanwhile its reached $10 \%$ in trades, transportation, and telecommunications (Department of Statistics, 2002).

One of the major problems of the Governorate is the disperse location of human settlements and of natural resources. Tourism activities are limited if not rare. The natural resources of the governorate are underground water, natural gas, and basalt zeolite. Average hospital beds are 10.8 for each 10000 compared to 16 in Jordan. Infants' hospital birth is $6.4 \%$ of Jordan's total infants born in hospitals. Disease like Zuhar Ameybi is 58.7\%, malti fever is $55 \%$, lung disease is $12.7 \%$, and lever disease is $10.3 \%$ of Jordan's total. Most of those who use health centers have military insurance (Department of Statistics, 2002).

Mafraq Governorate has four regions that include: (1) Mafraq center with 104,000 with 3 districts and 72 settlements of which 25 increases over 1000 people, (2) Northwest Badia and its center is al Al Al-Bayt University and have three districts with 71,000 population and 42 settlements eight of which increases over 1000 people, (3) Northeast Badia, Safawi is its center, and have four districts with 51,000 population and 67 settlements with 10 settlements that have more than 1000 population, and (4) Ruwaished is its center with population of 17,000 and twelve settlements, four of which its populated with more than 1000, see Figure 1 . The governorate has 18 municipalities that lack services and facilities for its local residents. These municipalities include: (1) Greater Mafraq, (2) New Bal'ama, (3) Zaa'tri and Mansheyya, (4) Hausha; (5) Baseleyyah; (6) AsSarhan; (7) Sabha and Dafyanah; (8) Safawi; (9) Umm Alquttayn and Makeyftah; (10) Bani Hashem; (11) New Rhab; (12) Mansheyyat Bani Hasan; (13) New Deyr Alkahf; (14) New Rweyshid: (15) AsSalhiyyah and Nayfah; (16) Alhusseyn bin Abdullah; (17) Khaldeyyah; (18) New Umm Aljmal (Department of Statistics, 2002). 


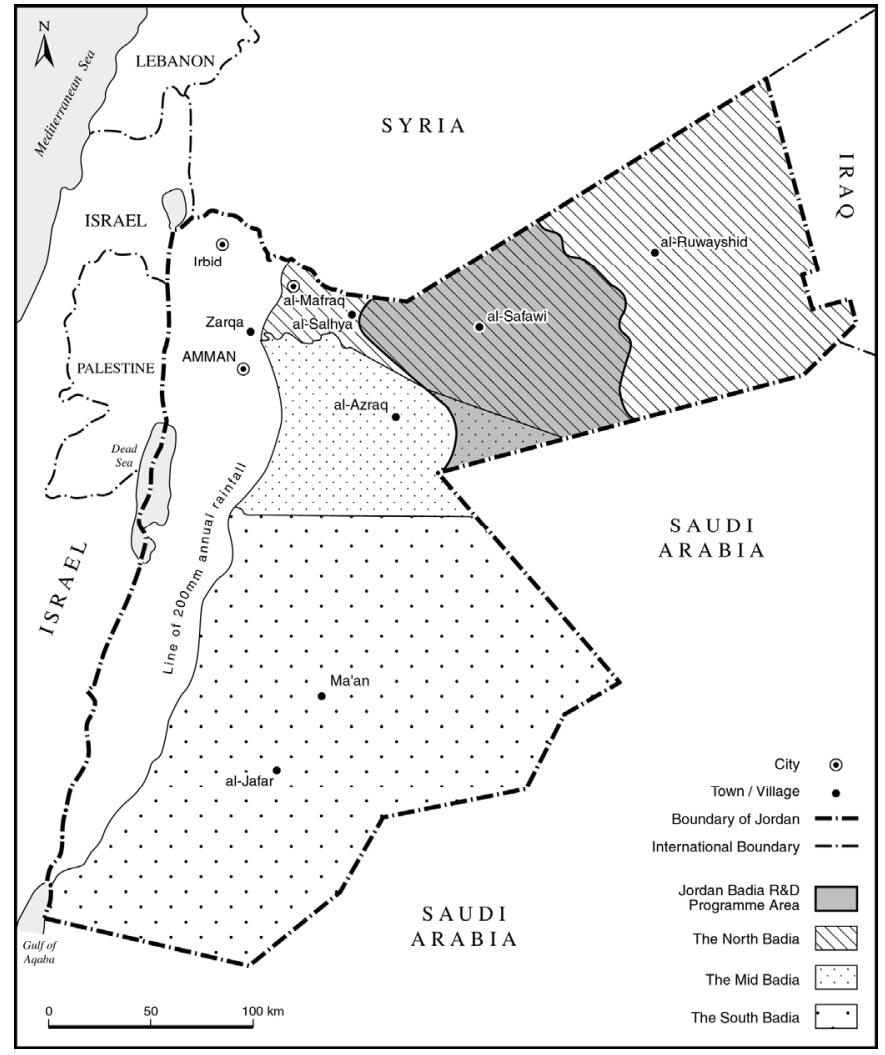

Figure 1. Jordan's map showing north badia region

Source: Al-Oun, 1997.

\subsubsection{Capacity of Education Supply}

There are three directorates in Mafraq Governorate: Mafraq Center, Northeast Badia, and Northwest Badia. Students' dropouts in Mafraq center are 255, of which 107 are females, and Northeast Badia 59 students, 30 of which are females. Infiltration may be for premature marriage, financial and living conditions and some students and their families, and lack of transportation (Department of Statistics, 2002).

The latest statistics shows that Mafraq Governorate have about 353 schools, of which 337 built by the Ministry of Education, one by the Military, One by the Ministry of Social development, two by UNRWA, eight by private sector, in addition to three private sector kindergartens. About 4206 teachers attend these schools $55 \%$ of which are females. The private sector provided 3 kinder gratins that host 415 kids taught by 13 teachers. Also there are eight private elementary schools with one that has one secondary section. Two schools are for males and the rest are mixed. Schools in Mafraq Governorate that are supported by the Ministry of Education in terms of gender are about 119 male schools, 81 female schools, and 137 mixed schools. In terms of level of education, there are about 231 schools at the primary level; 96 schools high schools with Academic stream; eight schools with mixed Academic and Vocational streams; and two schools with only vocational stream. In addition, stream distribution over high schools shows a total of 62 schools have trade stream, 297 have industrial, 106 have nursing, 28 have agriculture, 116 have child education, 143 have fashion production, 40 have beauty, and 29 have nutrition schools (Department of Statistics, 2002).

Further, the government launched a research and development center in cooperation with the Higher Council of Science and Technology and Geographic Association in UK for Studies and Sustainable Development. There are five IT centers in the governorate, in Safawi, Balaa'mah, Sabha, Mafraq, and Rhab. The Ministry of Social Affairs has one center for teaching the handicapped from the first to the fourth grade and hosts 18 students taught by 5 teachers (Department of Statistics, 2002). In addition, there is one public university in the governorate, which its students in 2010/2011 were 12092 of which 57.186\% were females. Admission rate from the governorate were 17\% in 1999/2000. Majors of study include educational sciences, human sciences, jurisdiction, law, political science, social sciences, financing and business administration, IT, science, and architecture. Teaching staff reached 174, of which 20 were females that hold Ph.D. in 2010/2011. About 1160 students from the governorate were attending different universities around Jordan, 675 of which were females (Department of 
Statistics, 2002; Al Al-Bayt Registration Office, 2011). Finally, there is one two-year college in the governorate located in Mafraq city and has 181 female students, and has two programs one academic and the other in business administration in 2000/2001. While about 553 students from Mafraq governorate attended different colleges around Jordan, about 456 of which were females (Department of Statistics, 2002).

\subsection{Conceptual Framework}

The above indicated the development and impact of education sector in Mafraq Govenerate on economic growth, promotion of equity, and reduction of poverty. How much of this outcome is the consequence of particular characteristics of the education systems and how much is due to weak linkages between education and labor markets?

From the previous review the following framework can be concluded:

- Investment in education is translated into higher economic growth and investment returns, improved income equality, and lower poverty. It is reflected in measures like available supply, incentives of supply, demand, and market failures. However, investment in education is challenged by globalization and knowledge economy, economy, demographic pressure, finance of education, pedagogical reforms, and education and migration. Education is a value chain that requires context understanding. Market challenges and university education includes co-operation with the market, privatization of higher education, marketing higher education, and marketing in higher education.

- Demand of the educational environment in the value chain is reflected in indications like opportunities of jobs and economic activities, training, and limitations of demand.

- Supply of the educational environment in the value chain includes the teaching-organizational, physical entities, and capacity of quality and quantity of supply, in addition to personality issues of the teacher and the student.

\subsection{Hypotheses of the Study}

Based on the above reviewed background and the assumption that Higher Education in Mafraq Governorate lacks supply of applied sciences majors (such as agriculture, engineering, architecture, nursery, medicine, arid land development, and resources management) at the local university level, it is hypothesized that:

1) Schools located in the three different directorates offer differences in overall students' perceived performance.

2) Schools of the three different directorates have differences in overall perceived performance over:

a) Capacity in quantity of the input of students' competitiveness at the elementary, eleventh, and twelveth grades.

b) Capacity in quantity of the supply of the teachers.

c) Capacity of the teaching-organizational entity, teaching-organization entity, and capacity of quality of supply.

d) Students' gender and school's education levels.

\section{Research Methods}

The hypotheses of the study were investigated based on field research using surveys. One leader for two teams of eight assistants conducted the field research.

\subsection{Field Research - Survey}

Surveys were conducted by interviewing a sample of schools administers from the four directorates in the North Badia region (Mafraq center, Northwest Badia, and Northeast Badia) representing the eighteen municipalities that included a target population of all elementary and secondary schools. Interviews took place inside the school building in the municipal office for the whole sample.

\subsection{Sampling Technique}

A stratified proportional random sample was used. Stratification was for the eighteen municipalities. The 18 municipalities (covering about 100 villages) included: (1) Greater Mafraq, (2) New Bal'ama, (3) Zaa'tri and Mansheyya, (4) Hausha; (5) Baseleyyah; (6) AsSarhan; (7) Sabha and Dafyanah; (8) Safawi; (9) Umm Alquttayn and Makeyftah; (10) Bani hashem; (11) New Rhab; (12) Mansheyyat Bani Hasan; (13) New Deyr Alkahf; (14) New Rweyshid: (15) AsSalhiyyah and Nayfah; (16) Alhusseyn bin Abdullah; (17) Khaldeyyah; (18) New Umm Aljmal. 
The total number of sample frame is 337 schools of which 231 for elementary education, and 96 secondary, 8 vocational and academic, and two vocational. The proportion is suggested to be about $60 \%-70 \%$ of the schools distributed over the three directorates and covering all the municipalities. So from each municipality only two-thirds of the total available schools were suggested to be interviewed from both female and male elementary and secondary schools. Randomization used the list of schools in each municipality which is alphabetically ordered. Selection was assigned randomly as every other school in the list until the proportion of $60-70 \%$ of the schools is achieved from each of the female and male elementary and secondary schools list. Final sample proportion was $67.9 \%$ with a size of 229 schools' administers. Response rate was $67.3 \%$ in Mafraq center, $42.3 \%$ in Northeast Badia, and $51.5 \%$ in Northwest Badia.

\subsection{Questionnaire Instrument}

The questionnaire included the following sections:

(1) Supply for manpower (human resources) capacity - Teaching Environment:

1.a. Capacity of supply at the schools level in terms of quantity: (1) School capacity - distribution across levels of education, gender, and pass and fail; (2) Available levels of study - distribution across gender and pass and fail; (3) Available fields of study - distribution across gender, and pass and fail; (4) High school education distribution across gender, fields of study, and pass and fail; and (5) Available teachers - distribution across majors, gender, age, teaching experience, and teaching efficacy and hours of teaching (time-use for teaching).

1.b. Capacity of supply at the schools level in terms of quality: (1) Perception of available teaching pedagogy; (2) Directing students to choose the track they may need by providing qualified teacher who provides supervision and guidance to students; and (3) Obstacles of concentration at the Ministry of Education Level: financial, specializations, incentives; (4) Evaluating the impact of implemented development program provided by the Ministry of Education and Ministry of Higher Educations on the local community - limitations and vision.

(2) Supply of the educational environment in the value chain includes the teaching-organizational and physical entities, reflected in quality and quantity, in addition to personality of the teacher and the student - School Environment:

2.a. Teaching-organizational entity includes understanding available human resources capacity in terms of quantity: (1) Strength of leadership ((a) instructional (educational) (teaching pedagogy), and (b) structural (organizational: hierarchy of authority, bureaucracy and hindrance (difficulty of authority), and participation decisions); (2) staff frustration; (3) positive classroom environment; (4) caring and support to students (esprit, intimacy, and student-centeredness); (5) formalization; and (6) students control (student control ideology-organizational ideology).

2.b. Physical entity include understanding classroom and school infrastructure and services: (1) Classroom environment include: classroom size, classroom arrangements, lighting, thermal conditions, and air quality; and (2) School environment include: school size, noise location, building age.

2.c. Other Variables that may affect the teaching-learning environment include: (1) student attitude towards the school, student affiliation and involvement, and students' competition; (2) teacher attitude and teacher performance; and (3) Availability of Services.

(3) Student performance - Learning efficacy of perceived qualitative performance or attainment test scores of average annual in all subjects such as: Science, Math, Physics, Chemistry, Biology, Geology, Computer Science, Arabic, \& English.

\section{Results and Analysis}

\subsection{Descriptive Statistics}

\subsubsection{Demographic Information of the Subjects}

Interviewed schools were located in the geographically dispersed area of Jordan's North Badia. Location of interviewed schools from the center of the main city of Mafraq ranged from the city itself to villages that were located $218 \mathrm{~km}$ away, see Table 1. The average distance from Mafraq City of the sampled schools from city of Mafraq is about $29 \mathrm{~km}$. 
Table 1. Descriptive statistics - characteristics of interviewed subjects

\begin{tabular}{llllllll}
\hline Variables & $\mathrm{N}$ & Range & Minimum & Maximum & Mean & $\begin{array}{l}\text { Std. } \\
\text { Deviation }\end{array}$ & Variance \\
\hline Village Distance from Mafraq City & 228 & 218 & 0 & 218 & 29.25 & 33.593 & 1128.499 \\
Subject's Gender & 229 & 1 & 1 & 2 & 1.55 & .499 & .249 \\
Educational Level & 229 & 5 & 1 & 6 & 3.08 & .914 & .836 \\
Training Workshops & 229 & 6 & 1 & 7 & 5.90 & 2.107 & 4.438 \\
Place of Residence & 229 & 3 & 1 & 4 & 1.49 & .589 & .347 \\
\hline
\end{tabular}

Interviewed subjects were about $45 \%$ males and $55 \%$ females, see Table 2 . Their education level ranged from college to Ph.D. and distributed as follows: Ph.D. (3.5\%), Masters (17.5\%), Diploma (56.3\%), Bachelor (13.5\%), and College (8.7\%), see Tables 8 and 9.

Table 2. Frequency distribution of major characteristics of interviewed subjects

\begin{tabular}{|c|c|c|c|c|}
\hline & & Frequency & Percent & Cumulative Percent \\
\hline \multicolumn{5}{|l|}{ Gender } \\
\hline Male & & 104 & 45.4 & 45.4 \\
\hline Female & & 125 & 54.6 & 100.0 \\
\hline \multicolumn{5}{|l|}{ Educational Level } \\
\hline Ph.D. & & 8 & 3.5 & 3.5 \\
\hline M.A./M.Sc. & & 40 & 17.5 & 21.0 \\
\hline Diploma & & 129 & 56.3 & 77.3 \\
\hline Bachelor & & 31 & 13.5 & 90.8 \\
\hline College & & 20 & 8.7 & 99.6 \\
\hline Other & & 1 & .4 & 100.0 \\
\hline \multicolumn{5}{|l|}{ Training Workshops } \\
\hline Management & & 25 & 10.9 & 10.9 \\
\hline Pedagogy & & 6 & 2.6 & 13.5 \\
\hline Computer Skills & & 13 & 5.7 & 19.2 \\
\hline Specialized & & 1 & .4 & 19.7 \\
\hline Other & & 2 & .9 & 20.5 \\
\hline None & & 12 & 5.2 & 25.8 \\
\hline More than One & & 170 & 74.2 & 100.0 \\
\hline \multicolumn{5}{|l|}{ Years of Service } \\
\hline$<5 \mathrm{Yrs}$ & & 76 & 33.2 & 33.2 \\
\hline 6-10 Yrs & & 57 & 24.9 & 58.1 \\
\hline $11-15$ Yrs & 26 & 11.4 & & 69.4 \\
\hline $16-20 \mathrm{Yrs}$ & 29 & 12.7 & & 82.1 \\
\hline $21-15$ Yrs & 23 & 10.0 & & 92.1 \\
\hline$>25 \mathrm{Yrs}$ & 18 & 7.8 & & 100.0 \\
\hline \multicolumn{5}{|l|}{ Place of Residence } \\
\hline Same Village/City & 127 & 55.5 & & 55.5 \\
\hline Another Village & 93 & 40.6 & & 96.1 \\
\hline Another City & 9 & 3.9 & & 100.0 \\
\hline Total & 229 & 100.0 & & 100.0 \\
\hline
\end{tabular}


$(10.9 \%)$, pedagogy $(2.6 \%)$, computer skills $(5.7 \%)$, and specialized workshops $(0.4 \%)$, see Tables 8 and 9 . In terms of years of service for the interviewed municipals they ranged from less than five years of service (33.2\%), 6-10 years (24.9\%), 11-15 years (11.4\%), 16-20 years (12.7\%), $21-15$ years $10 \%$, and more than 25 years $(7.8 \%)$ with about $50 \%$ of the subjects serving 6-10 years, see Table 9. In addition more than half of the sample was coming from the same towns they working at (55.5\%), about $40.6 \%$ coming from another village in the same North Badia regions, and only about 3.9\% are coming from outside the North Badia Region, see Tables 1 and 2.

\subsubsection{Descriptive Statistics of the Major Study Variables}

\subsection{2.a Capacity of Physical Entity of Educational Supply}

Capacity of the physical entity of the education supply includes understanding classroom and school infrastructure and services: (1) Classroom environment include: proper classroom size in terms of students numbers, classroom area, classroom size in terms of students numbers, classroom shape, classroom seats arrangement, classroom's furniture arrangement flexibility, attention to furniture and equipment so teachers can store their tools, natural and additional lighting sources, thermal conditions, air quality and natural ventilation; and (2) School environment include: availability of services such as computer labs, science labs, art studios, school library, indoor and outdoor sports facility, food facility, praying facility, school fencing, school gate, rest rooms, school size in terms of students numbers, school area, school quite location/noise location, and building maintenance.

(1) Classroom Environment: In terms of classroom area, it ranged from 4-48 square meters. However, most of the sample (73.7\%) has classroom area of 10-29 square meters. In regards to classroom size in terms of students' numbers, the number of students ranged from 2 to 50 students, with an average size of about 21 students. About half the sampled schools (52.8\%) have classroom size of less than 20 students. In regards to proper classroom size in terms of students' numbers, most of the sample agreed on its appropriateness (71.2\%). Classroom shapes were square, rectangular, and irregular. However, the most occurring shape is rectangular $(58.5 \%)$ and the least is irregular (2.6\%). In terms of classroom seats arrangement, most of the sample $(85.6 \%)$ agreed on its appropriateness. Also, about $54.2 \%$ of the sample agreed on classroom's furniture arrangement flexibility. Further, most of the sample (72.5\%) considered the attention to furniture and equipment so teachers can store their tools is appropriate. In terms of natural lighting sources, most of the sample agreed on its availability (90.8\%). Number of windows in classrooms ranged from 1-8, the most frequent occurrence of number of windows is two (48.5\%) indicated so. In terms of additional lighting sources, about two-thirds of the sample $(79.5 \%)$ agreed on its presence. Thermal conditions: only about half the sample agreed on its heat availability $(47.2 \%)$ and on about one-quarter $(26.2 \%)$ agreed on its cooling control. In regards to air quality and natural ventilation, most of the sample (87.3\%) agreed on its availability in classrooms.

(2) School Environment: In regards to availability of services such as computer labs, science labs, art studios, school library, indoor and outdoor sports facility, food facility, praying facility, school fencing, school gate, rest rooms, school size in terms of students numbers, school area, school quite location/noise location, and building maintenance. In terms of services, about $77.7 \%$ of the schools have computer labs, and only $42.4 \%$ has science labs, and $13.5 \%$ has art studios. On the other side, about half the sample has libraries (50.2\%) school library. Further, only $11.8 \%$ of the schools have indoor sports facilities, and $27.9 \%$ has outdoor sports facilities. In addition, about two-thirds (69\%) has food facility, and only $24 \%$ has praying facility. Further, about two-thirds (65.5\%) has school fencing, and about two-thirds (63.8\%) has school gates. Most of the schools (91.7) have rest rooms. On the other hand, school size, in terms of students' numbers, ranged from schools that have less than 50 students (about 6.2\%) to schools that has 500-757 students (only about 3.2\% of the sample). However, about $61.1 \%$ of the sample has schools of less than 150 students, and the most occurring number of students at sampled schools is 150-200 students (about 40.7\%). Meanwhile, school area ranged from 54-10000 square meters, with the most occurring area of 200-500 square meters (39.9\%). About half the sample (48\%) has area of less than 500 square meters. Further, $79 \%$ of the sample agreed on the schools being located in a quite zone and away from noise. In terms of building maintenance, about half of the sample (54.6\%) agreed it is well maintained.

\subsection{2.b Capacity of Quantity of Educational Supply}

Capacity of supply at the schools level in terms of quantity: (1) School capacity - distribution across levels of education, gender, and pass and fail; (2) Available levels of study - distribution across gender and pass and fail; (3) Available fields of study - distribution across gender, and pass and fail; (4) High school education distribution across gender, fields of study, and pass and fail; and (5) Available teachers - distribution across majors, gender, age, teaching experience, and teaching efficacy and hours of teaching (time-use for teaching).

(1) Schools Capacity - distribution across gender, levels of education, number of sections and students, 
and pass and fail: The distribution of gender across the sampled schools was as follows: $41.05 \%$ males, $19.65 \%$ females, and 39.30\% mixed genders, see Figures 2 and 3.

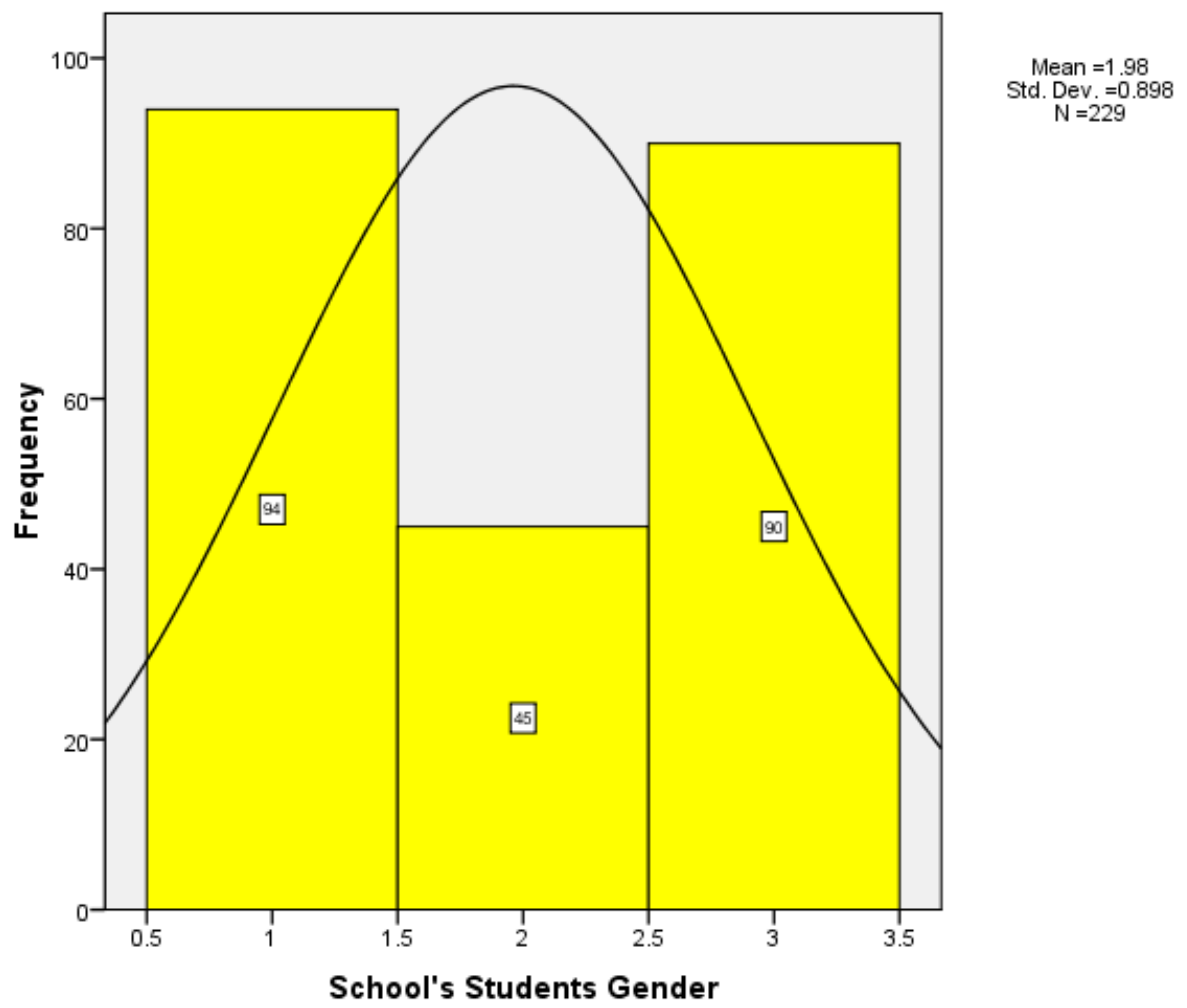

Figure 2. Distribution of students' gender across sampled schools (1 - Males, 2- Females, 3- Mixed Gender) The education level across the sampled schools was as follows: about $57.64 \%$ of schools were elementary, $10.48 \%$ secondary, and $31.88 \%$ have all levels, see Figures $2 \& 3$.

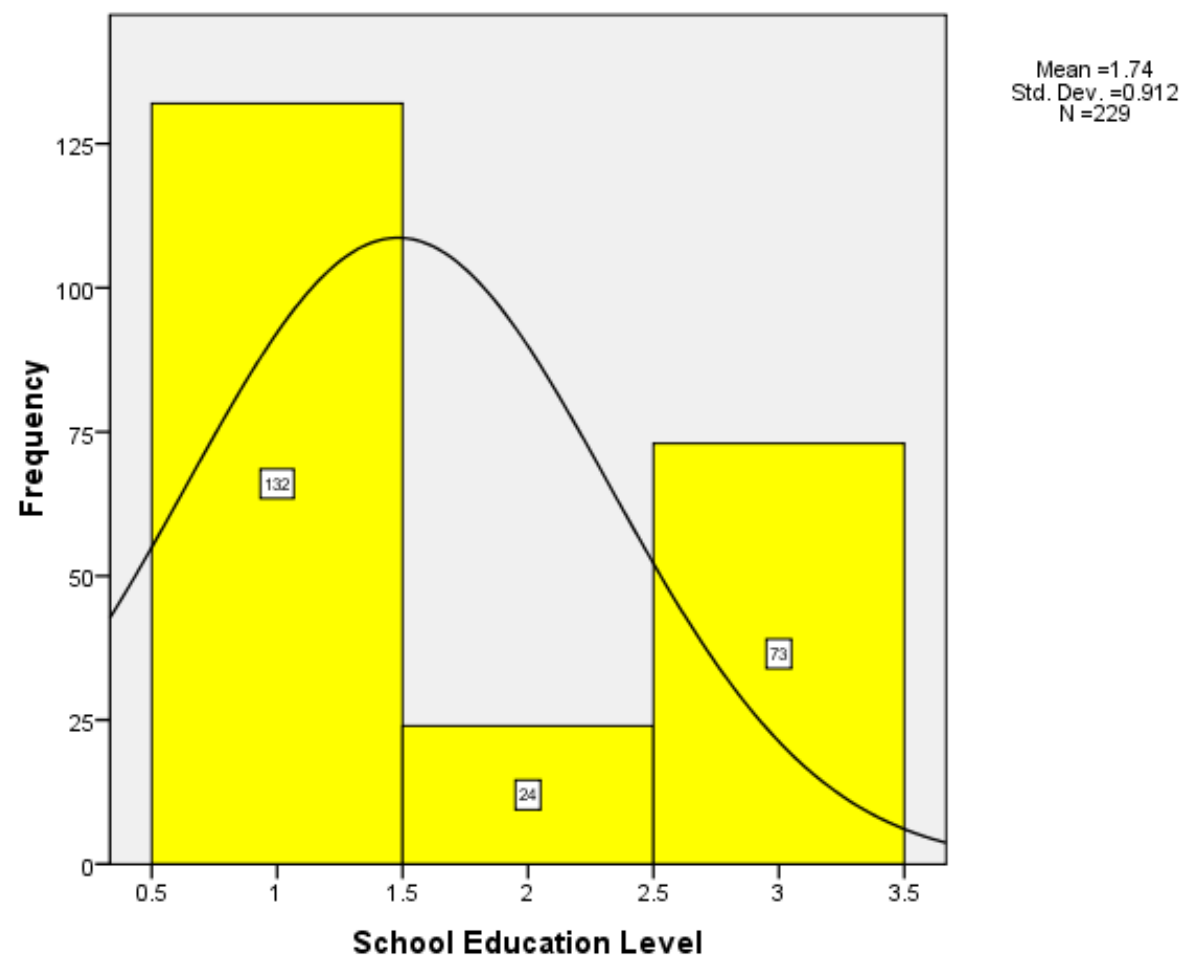

Figure 3. Distribution of education level across sampled schools (1 - Elementary, 2- Secondary, 3- All Levels)

Distribution across Elementary Stage: In terms of distribution of students sections, students' numbers, pass, 
and fail across of the sample, results showed the following:

1) $1^{\text {st }}$ grade - for the 115 schools who responded, sections ranged from 1-10, students numbers in these sections ranged from 5-165, and failing students ranged from 0-2.

2) $2^{\text {nd }}$ grade - for the 117 schools who responded, sections ranged from 1-3, students numbers in these sections ranged from 1-91, and failing students ranged from $0-1$.

3) $3^{\text {rd }}$ grade - for the 140 schools who responded, sections ranged from 1-4, students numbers in these sections ranged from 1-80, and failing students ranged from $0-4$.

4) $5^{\text {th }}$ grade - for the 153 schools who responded, sections ranged from 1-3, students numbers in these sections ranged from 1-101, and failing students ranged from 0-3.

5) $6^{\text {th }}$ grade - for the 146 schools who responded, sections ranged from 1-3, students numbers in these sections ranged from 1-102, and failing students ranged from 0-2.

6) $7^{\text {th }}$ grade - for the 140 schools who responded, sections ranged from 1-3, students numbers in these sections ranged from 1-121, and failing students ranged from 0-11.

7) $8^{\text {th }}$ grade - for the 130 schools who responded, sections ranged from 1-4, students numbers in these sections ranged from 2-145, and failing students ranged from 0-4.

8) $9^{\text {th }}$ grade - for the 122 schools who responded, sections ranged from 1-4, students numbers in these sections ranged from 2-137, and failing students ranged from 0-7.

9) $10^{\text {th }}$ grade - for the 111 schools who responded, sections ranged from 1-4, students numbers in these sections ranged from 2-137, and failing students ranged from 0-5.

Distribution across Eleventh Grade Stage: In terms of distribution of students sections, students' numbers, pass, and fail across of the sample, results showed the following:

1) $11^{\text {th }}$ grade/scientific - for the 48 schools who responded, sections ranged from 1-3, students numbers in these sections ranged from 1-124, and failing students ranged from 0-1.

2) $11^{\text {th }}$ grade/literature - for the 81 schools who responded, sections ranged from $1-2$, students numbers in these sections ranged from 3-60, and failing students ranged from $0-10$.

3) $11^{\text {th }}$ grade/computer - for the 12 schools who responded, sections ranged from 1-2, students numbers in these sections ranged from 14-89, and failing students were none.

4) $11^{\text {th }}$ grade/nursing - for the two schools who responded, sections were 1 , students numbers in these sections ranged from 7-24, and failing students were none.

5) $11^{\text {th }}$ grade/trade - for the one school who responded, sections were one, students numbers in the section was 18 , and failing students were none.

6) $11^{\text {th }}$ grade/industrial - for the one school who responded, but subject did not provide additional information about students' numbers and number of failing students.

7) $11^{\text {th }}$ grade/agricultural - for the one school who responded, sections were 1 , students numbers in the section was 37 , and failing students were none.

8) $11^{\text {th }}$ grade/management - for the one school who responded, sections were 1 , students numbers in the section was 3 , and failing students were none.

9) $11^{\text {th }}$ grade/vocational - for the four schools who responded, sections were 1-2, students numbers in these sections ranged from 14-31, and failing students were none.

10) $11^{\text {th }}$ grade/beauty - for the one school who responded, sections were 1 , students numbers in the section was 12 , and failing students were none.

Distribution across Twelfth Grade Stage (Tawjeehi): In terms of distribution of students sections, students' numbers, pass, and fail across of the sample, results indicated that there is one student in trade, one in agriculture, one in management, one in beauty, and none in industrial streams at the twelfth grade level as follows:

1) $12^{\text {th }}$ grade/scientific - for the 38 schools who responded, sections ranged from 1-4, students numbers in these sections ranged from 3-124, and failing students ranged from 0-15. 
2) $12^{\text {th }}$ grade/literature - for the 73 schools who responded, sections ranged from $1-2$, students numbers in these sections ranged from 3-55, and failing students ranged from 0-26.

3) $12^{\text {th }}$ grade/computer - for the 12 schools who responded, sections ranged from 1-2, students numbers in these sections ranged from 15-92, and failing students were 0-2.

4) $12^{\text {th }}$ grade/nursing - for the three schools who responded, sections were 1 , students numbers in these sections ranged from 9-25, and failing students were 0-3.

5) $12^{\text {th }}$ grade/trade - for the one school who responded, sections were one, students numbers in the section was 20, and failing students were 14 .

6) $12^{\text {th }}$ grade/industrial - no school from the sample has industrial at this level.

7) $12^{\text {th }}$ grade/agricultural - for the one school who responded, sections were 1 , students numbers in the section was 26 , and failing students were none.

8) $12^{\text {th }}$ grade/management - for the one school who responded, sections were 1 , students numbers in the section was 6 , and failing students were none.

9) $12^{\text {th }}$ grade/vocational - for the three schools who responded, sections were $1-2$, students numbers in these sections ranged from 15-25, and failing students were none.

10) $12^{\text {th }}$ grade/beauty - for the one school who responded, sections were 1 , students numbers in the section was 12 , and failing students were none.

(2) Available Teachers - Distribution across Majors, Age, Specialty, Teaching Experience (years of Service), and Teaching Efficacy and Hours of Teaching (Teaching Load Measured in Hours), Training Workshops, and Place of Residence:

1) Religion Teachers: ranged from 0-6 with a total number of 210, with age groups of 20 and above, served 0-24 years with an average of 7.7 years, and a teaching load of 0-61 hours with an average of 21.2 hours a week, and training of an average of 2-3 workshops who reside mostly in the North Badia region.

2) Arabic Teachers: ranged from 0-7 with a total number of 209, with age groups of 20 and above, served 0-30 years with an average of 9.4 years, and a teaching load of 0-123 hours with an average of 24.2 hours a week, and training of an average of 3-4 workshops who reside mostly in the North Badia region.

3) English Teachers: ranged from 1-6 with a total number of 214, with age groups of 20 and above, who has education of College and Bachelor degree, and served 0-25 years with an average of 7.1 years, and a teaching load of $0-87$ hours with an average of 22.8 hours a week, and training of an average of 3 workshops who reside mostly in the North Badia region.

4) Culture Teachers: ranged from 0-3 with a total number of 204 schools, with age groups of 20-50, who has education that ranged College to Ph.D. degree, and served 0-19 years with an average of 6.3 years, and a teaching load of 0-25 hours with an average of 17.0 hours a week, and training of an average of 2-3 workshops who reside mostly in the North Badia region.

5) Math Teachers: ranged from 0-6 with a total number of 203 schools, with age groups of 20 and above, who has education that ranged College to Ph.D. degree, and served 0-30 years with an average of 7.1 years, and a teaching load of 0-79 hours with an average of 22.1 hours a week, and training of an average of 2-3 workshops who reside mostly in the North Badia region.

6) Science Teachers: ranged from 0-6 with a total number of 191 schools, with age groups of 20 and above, who has education that ranged College to Master degree, and served 0-22 years with an average of 7.4 years, and a teaching load of 0-42 hours with an average of 20.2 hours a week, and training of an average of 3-4 workshops who reside mostly in the North Badia region.

7) Physics Teachers: ranged from 0-3 with a total number of 159 schools, with age groups of 20-50, who has education that ranged bachelor to master's degree, and served 0-16 years with an average of 5.2 years, and a teaching load of 0-32 hours with an average of 18.8 hours a week, and training of an average of 1-2 workshops who reside mostly in the North Badia region.

8) Chemistry Teachers: ranged from $0-2$ with a total number of 142 schools, with age groups of 20 and above, who has education that ranged from Bachelor Degree to Ph.D. degree, and served 0-16 years with an 
average of 4.6 years, and a teaching load of 0-24 hours with an average of 17.8 hours a week, and training of an average of 1-2 workshops who reside mostly in the North Badia region.

9) Biology Teachers: ranged from 0-2 with a total number of 138 schools, with age groups of 20 and above, who has education that ranged Bachelor to Ph.D. degree, and served 0-26 years with an average of 6.5 years, and a teaching load of 0-24 hours with an average of 16.7 hours a week, and training of an average of 1-2 workshops who reside mostly in the North Badia region.

10) Geology Teachers: ranged from 0-2 with a total number of 133 schools, with age groups of 20-40, who has education that ranged Bachelor to Master's degree, and served 1-15 years with an average of 5.0 years, and a teaching load of 7-21 hours with an average of 16.1 hours a week, and training of an average of 2-3 workshops who reside mostly in the North Badia region.

11) Computer Teachers: ranged from 0-8 with a total number of 161 schools, with age groups of 20 and above, who has education that ranged College to Master's degree, and served 0-17 years with an average of 4.0 years, and a teaching load of 0-38 hours with an average of 15.6 hours a week, and training of an average of 2-3 workshops who reside mostly in the North Badia region.

12) Geography Teachers: ranged from 0-6 with a total number of 164 schools, with age groups of 20 and above, who has education that ranged College to Master's degree, and served 0-17 years with an average of 5.7 years, and a teaching load of 0-28 hours with an average of 19.1 hours a week, and training of an average of 2-3 workshops who reside mostly in the North Badia region.

13) History Teachers: ranged from 0-3 with a total number of 151 schools, with age groups of 20-50, who has education that ranged College to Master's degree, and served $0-20$ years with an average of 7.1 years, and a teaching load of 0-27 hours with an average of 17.7 hours a week, and training of an average of 3-4 workshops who reside mostly in the North Badia region.

14) Arts Teachers: ranged from 0-6 with a total number of 131 schools, with age groups of 20-50, who has education that ranged College to Master's degree, and served 2-16 years with an average of 8.3 years, and a teaching load of 7-103 hours with an average of 19.4 hours a week, and training of an average of 2-3 workshops who reside mostly in the North Badia region.

15) Athletics Teachers: ranged from 0-6 with a total number of 129 schools, with age groups of 20-50, who has education that ranged College to Master's degree, and served 0-20 years with an average of 7.0 years, and a teaching load of 0-28 hours with an average of 18.4 hours a week, and training of an average of 2-3 workshops who reside mostly in the North Badia region..

16) Music Teachers: ranged from 0-1 with a total number of 61 schools, with age groups of 20-40, who has education that ranged Bachelor to Ph.D. degree, and served 0-15 years with an average of 5.5 years, and a teaching load of 0-21 hours with an average of 14.8 hours a week, and training of an average of 2-3 workshops who reside mostly in the North Badia region.

17) Languages Teachers: ranged from 0-8 with a total number of 69 schools, with age groups of 20-50, who has education that ranged Bachelor to Master's degree, and served 0-21 years with an average of 6.8 years, and a teaching load of 1-28 hours with an average of 21.4 hours a week, and training of an average of 5-6 workshops who reside mostly in the North Badia region.

4.1.2.c. Capacity of Teaching-Organizational Entity of the Supply and Capacity of Quality of Education Supply at the School Level and Other Variables

(1) Capacity of Teaching-Organizational Entity of the Supply: Instructional capacity was assessed with an average of 4 and a tendency of strong agreement; structural agreement was also with an average of 4.1 and a tendency of strong agreement; staff frustration has a tendency of disproval with an average of 2.6; positive classroom environment has a slight tendency of approval with an average of 3.7; caring and support for students has a slight tendency of approval with an average of 4; formalization has a tendency of strong agreement with an average of 4.2; and students control has a strong agreement with an average of 4.2, see Table 3.

(2) Capacity of Quality of Education Supply at the School Level: Perception of existing pedagogy has a slight tendency of approval with an average of 3.8; directing students to choose the right stream also received slight approval with an average of 3.5; and obstacles of Ministry of Education concentration has a tendency of agreement with an average of 4.0, see Table 3 .

(3) Other Variables: Included students attitude with a tendency of slight agreement ( $M=3.8)$; teachers attitude 
with tendency of agreement $(\mathrm{M}=3.98)$; available school services has a slight agreement with $\mathrm{M}=3.4$; and perceived students' performance has a tendency of slight agreement $\mathrm{M}=3.1$, see Table 3 .

Table 3. Descriptive statistics about independent variables - organizational entity \& capacity of quality of supply $\&$ other variables

N Range Minimum Maximum Mean Std. Variance

Deviation

\begin{tabular}{llllllll} 
Teaching-Organizational Entity & & & & & & & \\
Instructional & 229 & 2.40 & 2.60 & 5.00 & 4.0170 & .38732 & .150 \\
Structural & 229 & 3.67 & 1.33 & 5.00 & 4.1317 & .50557 & .256 \\
Staff Frustration & 229 & 4.00 & 1.00 & 5.00 & 2.6288 & .92454 & .855 \\
Positive Classroom Environment & 229 & 4.00 & 1.00 & 5.00 & 3.7810 & .77435 & .600 \\
Caring \& Support for Students & 229 & 4.00 & 1.00 & 5.00 & 3.9597 & .65705 & .432 \\
Formalization & 229 & 3.50 & 1.50 & 5.00 & 4.2329 & .51498 & .265 \\
Students Control & 229 & 2.50 & 2.50 & 5.00 & 4.2205 & .44125 & .195 \\
Quality of Education & & & & & & & \\
Perception of Existing Pedagogy & 229 & 3.50 & 1.50 & 5.00 & 3.8443 & .61237 & .375 \\
Directing Students Track & 229 & 4.00 & 1.00 & 5.00 & 3.4716 & .98356 & .967 \\
Obstacles of Ministry Concentration & 229 & 4.00 & 1.00 & 5.00 & 3.9502 & .76167 & .580 \\
Other Variables & & & & & & & \\
Students Attitude & 229 & 2.88 & 2.13 & 5.00 & 3.7718 & .53898 & .291 \\
Teachers Attitude & 229 & 3.33 & 1.67 & 5.00 & 3.9816 & .54591 & .298 \\
Available School Services & 229 & 3.89 & 1.00 & 4.89 & 3.3557 & .66320 & .440 \\
Perceived Students Performance - & & & & & & & \\
Learning Efficacy & 229 & 4.00 & 1.00 & 5.00 & 3.1009 & .67052 & .450 \\
\hline 4.1 .2$. Dep & & & & & & \\
\hline
\end{tabular}

4.1.2.d. Dependent Variable Overall Perceived Students' Performance

Overall perceived students' performance averaged 3.1, with a slight agreement. Meanwhile perceived students' performance in all subjects were as follows, see Table 4:

1) Science ranged from 1-5 with $\mathrm{M}=3.2$.

2) Math ranged from 1-5 with $M=2.9$.

3) Physics ranged from 1-5 with $\mathrm{M}=2.7$.

4) Chemistry ranged from 1-5 with $\mathrm{M}=2.9$.

5) Biology ranged from $1-5$ with $\mathrm{M}=3.1$.

6) Geology ranged from 1-5 with $\mathrm{M}=3.2$.

7) Computer Science ranged from 1-5 with $\mathrm{M}=3.4$.

8) Arabic ranged from 1-5 with $\mathrm{M}=3.7$.

9) English ranged from 1-5 with $\mathrm{M}=2.9$. 
Table 4. Descriptive statistics about dependent variable - perceived students performance / qualitative learning efficacy - education outputs

\begin{tabular}{llllllll}
\hline & N & Range & Minimum Maximum & Mean & $\begin{array}{l}\text { Std. } \\
\text { Deviation }\end{array}$ \\
\hline Overall Performance & 229 & & & & 3.1009 & .67052 \\
High Performance in Science & 229 & 4 & 1 & 5 & 3.23 & 1.023 & 1.047 \\
High Performance in Math & 229 & 4 & 1 & 5 & 2.85 & 1.066 & 1.136 \\
High Performance in Physics & 229 & 4 & 1 & 5 & 2.71 & .896 & .803 \\
High Performance in Chemistry & 229 & 4 & 1 & 5 & 2.87 & .918 & .842 \\
High Performance in Biology & 229 & 4 & 1 & 5 & 3.13 & .923 & .851 \\
High Performance in Geology & 229 & 4 & 1 & 5 & 3.18 & .907 & .823 \\
High Performance in Computer & 229 & 4 & 1 & 5 & 3.39 & .854 & .730 \\
Science & 229 & 4 & 1 & 5 & 3.67 & .835 & .696 \\
High Performance in Arabic & 229 & 4 & 1 & 5 & 2.88 & 1.077 & 1.160 \\
High Performance in English & & & & & & & \\
\hline
\end{tabular}

Frequency distribution of perceived students' performance in all subjects was as follows:

1) Science, about one-third of the sample does not agree that students have high performance in science, accumulative percent $=34.5 \%$.

2) Math, about half of the sample does not agree that students have high performance in Math, accumulative percent $=51.1 \%$.

3) Physics, about half of the sample does not agree that students have high performance in Physics, accumulative percent $=44.1 \%$.

4) Chemistry, about one-third of the sample does not agree that students have high performance in Chemistry, accumulative percent $=37.6 \%$.

5) Biology, about one-quarter of the sample does not agree that students have high performance in Biology, accumulative percent $=24.9 \%$.

6) Geology, about one-fifth of the sample does not agree that students have high performance in Geology, accumulative percent $=22.7 \%$.

7) Computer Science, about one-fifth of the sample does not agree that students have high performance in Computer Science, accumulative percent $=17.0 \%$.

8) Arabic, most of the sample agree that students have high performance in Arabic, accumulative percent $=$ $76.9 \%$.

9) English, about half of the sample do not agree that students have high performance in English, accumulative percent $=50.7 \%$.

\subsection{Cluster Analysis - Geographical Distribution}

The study collected data from subjects in three directorates of the North Badia region and their distribution as follows: Central Mafraq directorate 105 subjects, Northwest Badia directorate 56 subjects, and Northeast Badia directorate 68 subjects, see Table 5 and Figure 4. The percentage of the distributions is Central Mafraq 45.9\%, Northwest Badia 24.5\%, and Northeast Badia 29.7\%, see Figure 5 .

Table 5. Frequencies of North Badia directorates

\begin{tabular}{lllllll}
\hline \multirow{2}{*}{ Cluster } & \multicolumn{2}{l}{ Central Mafraq } & \multicolumn{2}{l}{ Northwest Bahia } & \multicolumn{2}{l}{ Northeast Badia } \\
\cline { 2 - 7 } & Frequency & Percent & Frequency & Percent & Frequency & Percent \\
\hline 1 - Central Mafraq & 105 & $100.0 \%$ & 0 & $.0 \%$ & 0 & $.0 \%$ \\
2 - Northwest Badia & 0 & $.0 \%$ & 56 & $100.0 \%$ & 0 & $.0 \%$ \\
3 - Northeast Badia & 0 & $.0 \%$ & 0 & $.0 \%$ & 68 & $100.0 \%$ \\
Combined & 105 & $100.0 \%$ & 56 & $100.0 \%$ & 68 & $100.0 \%$ \\
\hline
\end{tabular}




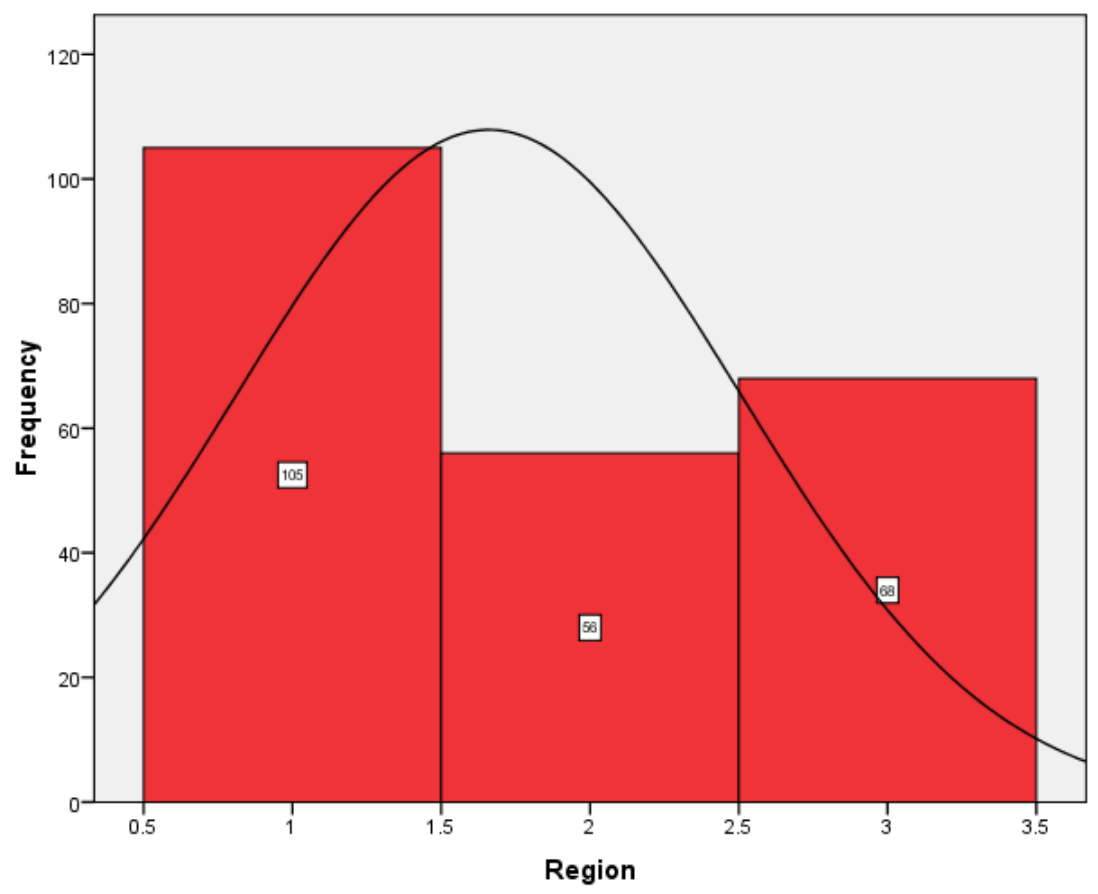

Figure 4. Distribution of sampled schools over three North Badia directorates

Within Cluster Percentage of Region

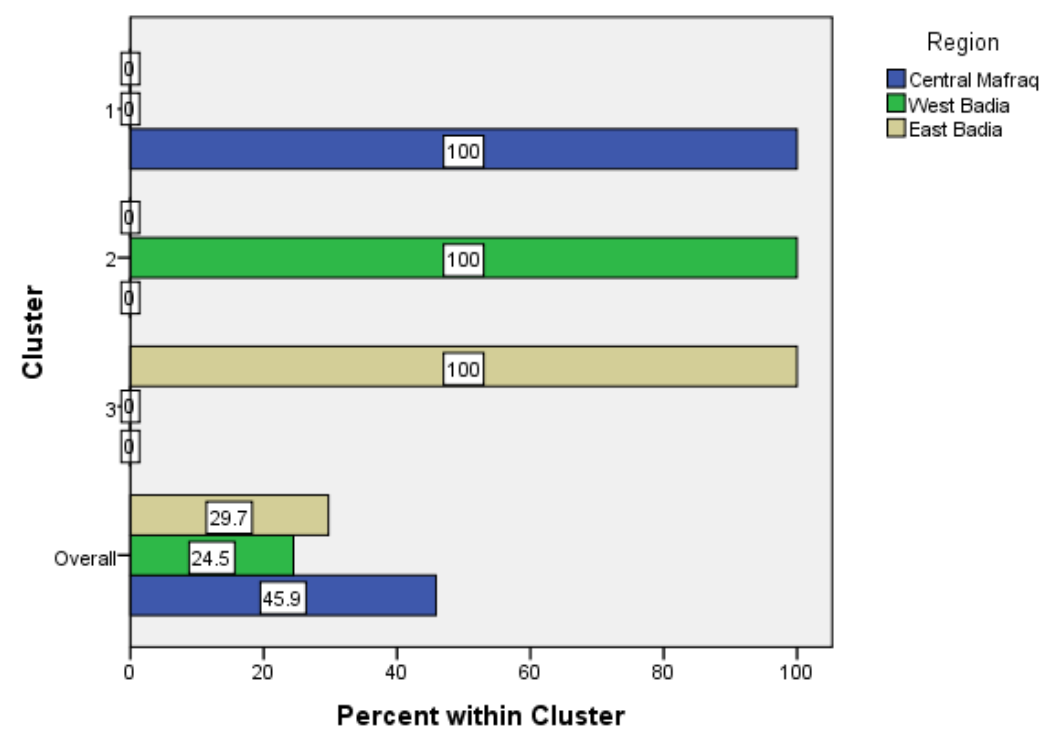

Figure 5. Attribute importance - within cluster percentage

Cluster analysis for Perceived Students Performance over these three directorates indicated that centroid is highest in Central Mafraq $\mathrm{M}=3.153$ and the least is in Northeast Badia $\mathrm{M}=2.995$; whilst for both Central Mafraq and Northwest Badia $(M=3.131)$ it is higher than the combined group $(M=3.101)$, see Table 6 and Figure 6.

Table 6. Cluster profile centroids - perceived students performance - overall learning efficacy

\begin{tabular}{lcc}
\hline Cluster & Mean & Std. Deviation \\
\hline $\mathbf{1}$ - Central Mafraq & 3.153 & .702 \\
$\mathbf{2}$ - Northwest Bahia & 3.131 & .687 \\
3 - Northeast Bahia & 2.995 & .601 \\
Combined & 3.101 & .67052 \\
\hline
\end{tabular}




\section{Simultaneous 95\% Confidence Intervals for Means}

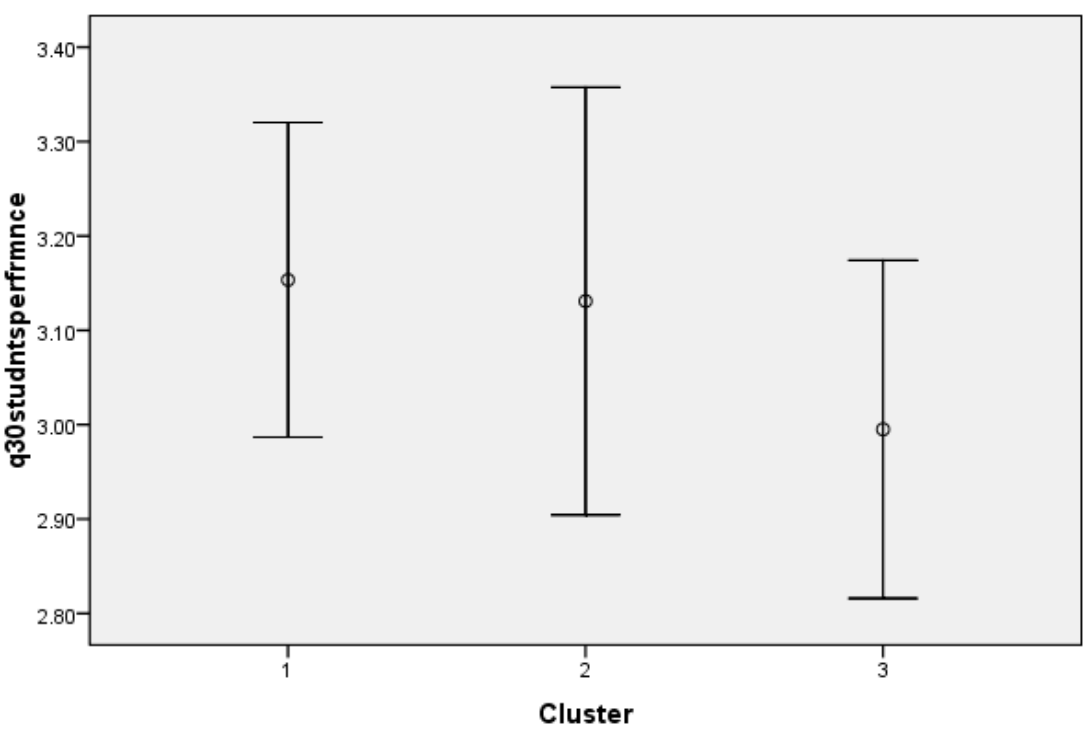

Figure 6. Attribute importance - within cluster variation

\subsection{Relationship between North Badia Directorates and Student Performance}

In order to test the hypothesis that schools located in the three different directorates offer quality and quantity in the educational environments physically and organizationally differently the following statistical Multi-level Analysis of North Badia Directorates over overall students' performance, quantitative and qualitative inputs of supply, as well as, teaching organization were carried out.

\subsubsection{Paired Test - Overall Perceived Students' Performance over North Badia Directorates}

Paired test for the perceived overall students' performance over the three directorates of the North Badia indicated significant effect $t=16.797$, see Table 7. Where Perceived Students Performance - Overall Learning Efficacy has a mean of $\mathrm{M}=3.101$, see Table 8 .

Table 7. Paired samples test - overall learning efficacy over North Badia directorates

\begin{tabular}{|c|c|c|c|c|c|c|c|c|}
\hline \multirow[t]{3}{*}{ Pair 1} & \multicolumn{5}{|c|}{ Paired Differences } & \multirow[t]{3}{*}{$\mathbf{t}$} & \multirow[t]{3}{*}{ df } & \multirow{3}{*}{$\begin{array}{l}\text { Sig. } \\
\text { (2-tailed) }\end{array}$} \\
\hline & \multirow[t]{2}{*}{ Mean } & \multirow[t]{2}{*}{$\begin{array}{l}\text { Std. } \\
\text { Deviation }\end{array}$} & \multirow[t]{2}{*}{$\begin{array}{l}\text { Std. } \\
\text { Error } \\
\text { Mean }\end{array}$} & \multicolumn{2}{|c|}{$\begin{array}{l}95 \% \text { Confidence } \\
\text { Interval of the } \\
\text { Difference }\end{array}$} & & & \\
\hline & & & & Lower & Upper & & & \\
\hline $\begin{array}{l}\text { Perceived Students Performance - } \\
\text { Learning Efficacy - North Badia } \\
\text { Regions }\end{array}$ & 1.262 & 1.137 & $.0752=$ & 1.114 & 1.410 & 16.797 & 228 & .000 \\
\hline
\end{tabular}

Table 8. Paired samples statistics - overall learning efficacy over North Badia directorates

\begin{tabular}{lllll}
\hline Pair 1 & Mean & N & Std. Deviation & Std. Error Mean \\
\hline $\begin{array}{l}\text { Perceived Students } \\
\text { Performance - Overall }\end{array}$ & 3.101 & 229 & .671 & $\mathbf{. 0 4 4}$ \\
$\begin{array}{l}\text { Learning Efficacy } \\
\text { North Badia Regions }\end{array}$ & 1.84 & 229 & .856 & \\
\hline
\end{tabular}

4.3.2 ANOVA Test - Effect of Overall Perceived Performance by Quantitative Inputs of Supply - Students over North Badia Region

Further analysis was carried out to investigate the effect of North Badia Directorates over capacity of quantity of Education Supply of students using anova test, as well as differences of the three North Badia Directorates using 
Scheffe Multiple Comparisons as the following displays:

\section{A. Quantitative Inputs of Elementary Stage Supply (Numbers of Sections and Students) over North Badia Region}

The test of effect of directorates of North Badia Region over capacity of quantity of Education Supply at the Elementary stage using anova test (Table 9), indicated that numbers of students at the elementary level are affected by geographical distribution for grades of $3^{\text {rd }}$ to $7^{\text {th }}$.

Table 9. ANOVA Test - elementary stage students input/capacity of quantity of supply over North Badia directorates

\begin{tabular}{|c|c|c|c|c|c|}
\hline Variable & Sum of Sq & df & Mean Square & $\mathrm{F}$ & Sig. \\
\hline $1^{\text {st }}$ Grade No. of Sections & 1.137 & 2 & .569 & .417 & .660 \\
\hline $1^{\text {st }}$ Grade No. of Students & 2838.318 & 2 & 1419.159 & 2.225 & .113 \\
\hline $2^{\text {nd }}$ Grade No. of Sections & .147 & 2 & .073 & .106 & .900 \\
\hline $2^{\text {nd }}$ Grade No. of Students & 1171.488 & 2 & 585.744 & 1.429 & .244 \\
\hline $3^{\text {rd }}$ Grade No. of Sections & .251 & 2 & .126 & .196 & .822 \\
\hline $3^{\text {rd }}$ Grade No. of Students & $\underline{2853.795}$ & $\underline{2}$ & $\underline{1426.898}$ & $\underline{5.014}$ & .008 \\
\hline $4^{\text {th }}$ Grade No. of Sections & .358 & $\underline{2}$ & .179 & .317 & .729 \\
\hline $4^{\text {th }}$ Grade No. of Students & 2996.445 & $\underline{2}$ & 1498.222 & $\underline{4.619}$ & .011 \\
\hline $5^{\text {th }}$ Grade No. of Sections & .685 & $\underline{2}$ & .342 & .651 & .522 \\
\hline $5^{\text {th }}$ Grade No. of Students & $\underline{5465.396}$ & $\underline{2}$ & $\underline{2732.698}$ & $\underline{7.560}$ & .001 \\
\hline $6^{\text {th }}$ Grade No. of Sections & 1.141 & $\underline{2}$ & .570 & $\underline{1.024}$ & .361 \\
\hline $6^{\text {th }}$ Grade No. of Students & $\underline{4158.418}$ & $\underline{2}$ & $\underline{2079.209}$ & $\underline{4.989}$ & .008 \\
\hline $7^{\text {th }}$ Grade No. of Sections & $\underline{1.326}$ & $\underline{2}$ & .663 & .924 & .398 \\
\hline $7^{\text {th }}$ Grade No. of Students & $\underline{6108.010}$ & $\underline{2}$ & $\underline{3054.005}$ & $\underline{5.377}$ & .006 \\
\hline $8^{\text {th }}$ Grade No. of Sections & $\underline{3.145}$ & $\underline{2}$ & $\underline{1.573}$ & $\underline{2.032}$ & .134 \\
\hline $8^{\text {th }}$ Grade No. of Students & 2721.911 & 2 & 1360.955 & 1.891 & .155 \\
\hline $9^{\text {th }}$ Grade No. of Sections & 3.062 & 2 & 1.531 & 2.044 & .132 \\
\hline $9^{\text {th }}$ Grade No. of Students & 3464.033 & 2 & 1732.017 & 2.476 & .088 \\
\hline $10^{\text {th }}$ Grade No. of Sections & .896 & 2 & .448 & .633 & .532 \\
\hline $10^{\text {th }}$ Grade No. of Students & 1199.756 & 2 & 599.878 & .793 & .455 \\
\hline
\end{tabular}

However, differences of the capacity of quantity of Education Supply in three North Badia directorates were investigated using Scheffe Multiple Comparisons. Results in Table 10 indicated:

1) At third grade students numbers showed a difference in means of supply $(\mathrm{M}(\mathrm{I}-\mathrm{J})=-10.369)$ between Central Mafraq \& Northeast Badia, where Central Mafraq shows lower performance than Northeast Badia; as well as, Northwest Badia \& Northeast Badia $(\mathrm{M}(\mathrm{I}-\mathrm{J})=-9.955)$, where Northwest Badia shows lower performance than Northeast Badia.

2) At fourth grade students numbers showed a difference in means of supply (M(I-J) $=-10.035)$ between Central Mafraq \& Northeast Badia, where Central Mafraq shows lower performance than Northeast Badia.

3) At fifth grade students numbers showed a difference in means of supply (M(I-J) $=-14.214)$ between Central Mafraq \& Northeast Badia, where Central Mafraq shows lower performance than Northeast Badia.

4) At Sixth Grade, students numbers showed a difference in means of supply (M(I-J) $=-12.778)$ between Central Mafraq \& Northeast Badia, where Central Mafraq shows lower performance than Northeast Badia.

5) At Seventh Grade, students numbers showed a difference in means of supply $(\mathrm{M}(\mathrm{I}-\mathrm{J})=-15.755)$ between Central Mafraq \& Northeast Badia, where Central Mafraq shows lower performance than Northeast Badia. 
Table 10. Scheffe multiple comparisons - elementary stage students input/capacity of quantity of supply over North Badia directorates

\begin{tabular}{|c|c|c|c|c|c|c|c|}
\hline \multirow[t]{2}{*}{ Dependent Variable } & \multirow{2}{*}{$\begin{array}{l}\text { (I) North Badia } \\
\text { Directorates }\end{array}$} & \multirow{2}{*}{$\begin{array}{l}\text { (J) North Badia } \\
\text { Directorates }\end{array}$} & \multirow{2}{*}{$\begin{array}{l}\text { Mean } \\
\text { Difference } \\
(\mathrm{I}-\mathrm{J})\end{array}$} & \multirow{2}{*}{$\begin{array}{l}\text { Std. } \\
\text { Error }\end{array}$} & \multirow[t]{2}{*}{ Sig. } & \multicolumn{2}{|c|}{$95 \%$ Confidence Interval } \\
\hline & & & & & & $\begin{array}{l}\text { Lower } \\
\text { Bound }\end{array}$ & $\begin{array}{l}\text { Upper } \\
\text { Bound }\end{array}$ \\
\hline \multirow[t]{4}{*}{$\begin{array}{l}1^{\text {st }} \text { Grade No. of } \\
\text { Sections }\end{array}$} & Central Mafraq & $\begin{array}{l}\text { Northwest } \\
\text { Badia }\end{array}$ & .045 & .193 & .973 & -.43 & .52 \\
\hline & & Northeast Badia & -.133 & .182 & .764 & -.58 & .31 \\
\hline & Northwest Badia & Central Mafraq & -.045 & .193 & .973 & -.52 & .43 \\
\hline & & Northeast Badia & -.179 & .211 & .699 & -.70 & .34 \\
\hline \multirow[t]{4}{*}{$\begin{array}{l}1^{\text {st }} \text { Grade No. of } \\
\text { Students }\end{array}$} & Central Mafraq & $\begin{array}{l}\text { Northwest } \\
\text { Badia }\end{array}$ & 2.085 & 5.778 & .937 & -12.25 & 16.42 \\
\hline & & Northeast Badia & -10.436 & 5.714 & .193 & -24.61 & 3.74 \\
\hline & Northwest Badia & Central Mafraq & -2.085 & 5.778 & .937 & -16.42 & 12.25 \\
\hline & & Northeast Badia & -12.521 & 6.577 & .168 & -28.84 & 3.80 \\
\hline \multirow[t]{4}{*}{$\begin{array}{l}2^{\text {nd }} \text { Grade No. of } \\
\text { Sections }\end{array}$} & Central Mafraq & $\begin{array}{l}\text { Northwest } \\
\text { Badia }\end{array}$ & .061 & .138 & .908 & -.28 & .40 \\
\hline & & Northeast Badia & .005 & .130 & .999 & -.31 & .32 \\
\hline & Northwest Badia & Central Mafraq & -.061 & .138 & .908 & -.40 & .28 \\
\hline & & Northeast Badia & -.056 & .150 & .934 & -.43 & .31 \\
\hline \multirow[t]{4}{*}{$\begin{array}{l}2^{\text {nd }} \text { Grade No. of } \\
\text { Students }\end{array}$} & Central Mafraq & $\begin{array}{l}\text { Northwest } \\
\text { Badia }\end{array}$ & 4.196 & 4.618 & .663 & -7.26 & 15.65 \\
\hline & & Northeast Badia & -4.632 & 4.518 & .593 & -15.84 & 6.57 \\
\hline & Northwest Badia & Central Mafraq & -4.196 & 4.618 & .663 & -15.65 & 7.26 \\
\hline & & Northeast Badia & -8.828 & 5.230 & .245 & -21.80 & 4.14 \\
\hline \multirow[t]{4}{*}{$\begin{array}{l}3^{\text {rd }} \text { Grade No. of } \\
\text { Sections }\end{array}$} & Central Mafraq & $\begin{array}{l}\text { Northwest } \\
\text { Badia }\end{array}$ & .050 & .132 & .931 & -.28 & .38 \\
\hline & & Northeast Badia & .075 & .125 & .834 & -.23 & .38 \\
\hline & Northwest Badia & Central Mafraq & -.050 & .132 & .931 & -.38 & .28 \\
\hline & & Northeast Badia & .025 & .144 & .985 & -.33 & .38 \\
\hline \multirow[t]{4}{*}{$\underline{\underline{3^{\text {rd }} \text { Grade No. of }}}$} & $\underline{\text { Central Mafraq }}$ & $\begin{array}{l}\text { Northwest } \\
\text { Badia }\end{array}$ & -.414 & 3.535 & .993 & -9.16 & 8.33 \\
\hline & & $\underline{\text { Northeast Badia }}$ & $-10.369^{*}$ & $\underline{3.437}$ & .012 & -18.88 & -1.86 \\
\hline & Northwest Badia & Central Mafraq & .414 & 3.535 & .993 & -8.33 & 9.16 \\
\hline & & Northeast Badia & $-9.955^{*}$ & $\underline{4.008}$ & .049 & -19.87 & -.04 \\
\hline \multirow[t]{4}{*}{$\begin{array}{l}4^{\text {th }} \text { Grade No. of } \\
\text { Sections }\end{array}$} & Central Mafraq & $\begin{array}{l}\text { Northwest } \\
\text { Badia }\end{array}$ & .099 & .124 & .729 & -.21 & .41 \\
\hline & & Northeast Badia & .039 & .117 & .946 & -.25 & .33 \\
\hline & Northwest Badia & Central Mafraq & -.099 & .124 & .729 & -.41 & .21 \\
\hline & & Northeast Badia & -.060 & .136 & .907 & -.39 & .27 \\
\hline \multirow[t]{4}{*}{$\underline{\underline{4^{\text {th }} \text { Grade No. of }}}$} & $\underline{\text { Central Mafraq }}$ & $\begin{array}{l}\text { Northwest } \\
\text { Badia }\end{array}$ & -.876 & 3.540 & .970 & -9.62 & 7.87 \\
\hline & & $\underline{\text { Northeast Badia }}$ & $-10.035^{*}$ & $\underline{3.429}$ & .015 & -18.51 & -1.56 \\
\hline & Northwest Badia & Central Mafraq & .876 & 3.540 & .970 & -7.87 & 9.62 \\
\hline & & Northeast Badia & -9.159 & 3.983 & .074 & -19.00 & .68 \\
\hline $\begin{array}{l}5^{\text {th }} \text { Grade No. of } \\
\text { Sections }\end{array}$ & Central Mafraq & $\begin{array}{l}\text { Northwest } \\
\text { Badia }\end{array}$ & .121 & .120 & .600 & -.17 & .42 \\
\hline
\end{tabular}




\begin{tabular}{|c|c|c|c|c|c|c|c|}
\hline & & Northeast Badia & -.013 & .113 & .993 & -.29 & .26 \\
\hline & Northwest Badia & Central Mafraq & -.121 & .120 & .600 & -.42 & .17 \\
\hline & & Northeast Badia & -.134 & .131 & .590 & -.46 & .19 \\
\hline \multirow[t]{4}{*}{$\frac{5^{\text {th }} \text { Grade No. of }}{\text { Students }}$} & $\underline{\text { Central Mafraq }}$ & $\begin{array}{l}\text { Northwest } \\
\text { Badia }\end{array}$ & -5.174 & 3.847 & .407 & -14.68 & 4.34 \\
\hline & & Northeast Badia & $-14.214^{*}$ & 3.655 & .001 & -23.25 & -5.18 \\
\hline & Northwest Badia & Central Mafraq & 5.174 & 3.847 & .407 & -4.34 & 14.68 \\
\hline & & Northeast Badia & -9.040 & 4.318 & .115 & -19.72 & 1.64 \\
\hline \multirow[t]{4}{*}{$\begin{array}{l}6^{\text {th }} \text { Grade No. of } \\
\text { Sections }\end{array}$} & Central Mafraq & $\begin{array}{l}\text { Northwest } \\
\text { Badia }\end{array}$ & .158 & .124 & .441 & -.15 & .46 \\
\hline & & Northeast Badia & .124 & .116 & .568 & -.16 & .41 \\
\hline & Northwest Badia & Central Mafraq & -.158 & .124 & .441 & -.46 & .15 \\
\hline & & Northeast Badia & -.035 & .135 & .967 & -.37 & .30 \\
\hline \multirow[t]{4}{*}{$\frac{6^{\text {th }} \text { Grade No. of }}{\text { Students }}$} & Central Mafraq & $\begin{array}{l}\text { Northwest } \\
\text { Badia }\end{array}$ & -2.832 & 4.230 & .799 & -13.29 & 7.63 \\
\hline & & Northeast Badia & $-12.778^{*}$ & $\underline{4.074}$ & .009 & -22.86 & -2.70 \\
\hline & Northwest Badia & Central Mafraq & 2.832 & 4.230 & .799 & -7.63 & 13.29 \\
\hline & & Northeast Badia & -9.946 & 4.819 & .123 & -21.87 & 1.97 \\
\hline \multirow[t]{4}{*}{$\begin{array}{l}7^{\text {th }} \text { Grade No. of } \\
\text { Sections }\end{array}$} & Central Mafraq & $\begin{array}{l}\text { Northwest } \\
\text { Badia }\end{array}$ & -.180 & .140 & .441 & -.53 & .17 \\
\hline & & Northeast Badia & -.118 & .132 & .671 & -.44 & .21 \\
\hline & Northwest Badia & Central Mafraq & .180 & .140 & .441 & -.17 & .53 \\
\hline & & Northeast Badia & .062 & .153 & .921 & -.31 & .44 \\
\hline \multirow[t]{4}{*}{$\underline{7^{\text {th }} \text { Grade No. of }}$} & Central Mafraq & $\begin{array}{l}\text { Northwest } \\
\text { Badia }\end{array}$ & -7.256 & 4.936 & .342 & -19.47 & 4.96 \\
\hline & & Northeast Badia & $-15.755^{*}$ & $\underline{4.818}$ & .006 & -27.68 & -3.83 \\
\hline & Northwest Badia & Central Mafraq & 7.256 & 4.936 & .342 & -4.96 & 19.47 \\
\hline & & Northeast Badia & -8.499 & 5.436 & .298 & -21.95 & 4.95 \\
\hline \multirow[t]{4}{*}{$\begin{array}{l}8^{\text {th }} \text { Grade No. of } \\
\text { Sections }\end{array}$} & Central Mafraq & $\begin{array}{l}\text { Northwest } \\
\text { Badia }\end{array}$ & -.257 & .146 & .212 & -.62 & .10 \\
\hline & & Northeast Badia & -.213 & .137 & .300 & -.55 & .12 \\
\hline & Northwest Badia & Central Mafraq & .257 & .146 & .212 & -.10 & .62 \\
\hline & & Northeast Badia & .044 & .159 & .962 & -.35 & .44 \\
\hline \multirow[t]{4}{*}{$\begin{array}{l}8^{\text {th }} \text { Grade No. of } \\
\text { Students }\end{array}$} & Central Mafraq & $\begin{array}{l}\text { Northwest } \\
\text { Badia }\end{array}$ & -.423 & 5.752 & .997 & -14.67 & 13.82 \\
\hline & & Northeast Badia & -10.145 & 5.616 & .200 & -24.06 & 3.77 \\
\hline & Northwest Badia & Central Mafraq & .423 & 5.752 & .997 & -13.82 & 14.67 \\
\hline & & Northeast Badia & -9.722 & 6.201 & .296 & -25.08 & 5.64 \\
\hline \multirow[t]{4}{*}{$\begin{array}{l}9^{\text {th }} \text { Grade No. of } \\
\text { Sections }\end{array}$} & Central Mafraq & $\begin{array}{l}\text { Northwest } \\
\text { Badia }\end{array}$ & -.269 & .143 & .174 & -.62 & .08 \\
\hline & & Northeast Badia & -.187 & .135 & .383 & -.52 & .14 \\
\hline & Northwest Badia & Central Mafraq & .269 & .143 & .174 & -.08 & .62 \\
\hline & & Northeast Badia & .082 & .156 & .871 & -.30 & .47 \\
\hline \multirow[t]{3}{*}{$\begin{array}{l}9^{\text {th }} \text { Grade No. of } \\
\text { Students }\end{array}$} & Central Mafraq & $\begin{array}{l}\text { Northwest } \\
\text { Badia }\end{array}$ & -2.681 & 5.833 & .900 & -17.14 & 11.78 \\
\hline & & Northeast Badia & -12.491 & 5.734 & .098 & -26.71 & 1.72 \\
\hline & Northwest Badia & Central Mafraq & 2.681 & 5.833 & .900 & -11.78 & 17.14 \\
\hline
\end{tabular}




\begin{tabular}{|c|c|c|c|c|c|c|c|}
\hline & & Northeast Badia & -9.810 & 6.325 & .304 & -25.49 & 5.87 \\
\hline \multirow[t]{4}{*}{$\begin{array}{l}10^{\text {th }} \text { Grade No. of } \\
\text { Sections }\end{array}$} & Central Mafraq & $\begin{array}{l}\text { Northwest } \\
\text { Badia }\end{array}$ & -.056 & .139 & .922 & -.40 & .29 \\
\hline & & Northeast Badia & -.147 & .131 & .532 & -.47 & .18 \\
\hline & Northwest Badia & Central Mafraq & .056 & .139 & .922 & -.29 & .40 \\
\hline & & Northeast Badia & -.091 & .152 & .834 & -.47 & .28 \\
\hline \multirow[t]{4}{*}{$\begin{array}{l}10^{\text {th }} \text { Grade No. of } \\
\text { Students }\end{array}$} & Central Mafraq & $\begin{array}{l}\text { Northwest } \\
\text { Badia }\end{array}$ & 4.130 & 6.426 & .814 & -11.82 & 20.08 \\
\hline & & Northeast Badia & -4.524 & 6.191 & .766 & -19.89 & 10.84 \\
\hline & Northwest Badia & Central Mafraq & -4.130 & 6.426 & .814 & -20.08 & 11.82 \\
\hline & & Northeast Badia & -8.655 & 6.888 & .457 & -25.75 & 8.44 \\
\hline
\end{tabular}

*. The mean difference is significant at the 0.05 level.

\section{B. Quantitative Inputs of Eleventh Grade Stage Supply over North Badia Directirates}

The test of effect of directorates of North Badia Directirates over capacity of quantity of Education Supply at the Eleventh Grade stage using Anova Test of Variance (Table 11), indicated that numbers of students in the scientific stream are affected by geographical distribution. In addition, number of sections in the Literature and Computer streams is affected by geographical distribution.

Table 11. ANOVA - eleventh grade stage students input/capacity of quantity of supply over North Badia directorates

\begin{tabular}{llllll}
\hline Variable & Sum of Squares & df & Mean Square & F & Sig. \\
\hline Scientific $/ 11^{\text {th }}$ Grade No. of Sections & 1.189 & 2 & .594 & 2.628 & .074 \\
Scientific $/ 11^{\text {th }}$ Grade No. of Students & 2185.373 & 2 & 1092.686 & 3.381 & .043 \\
$\underline{\text { Literature } / 11^{\text {th }} \text { Grade No. of Sections }}$ & 3.851 & 2 & 1.925 & 7.608 & .001 \\
Literature $/ 11^{\text {th }}$ Grade No. of Students & 96.908 & 2 & 48.454 & .516 & .599 \\
Computer $/ 11^{\text {th }}$ Grade No. of Sections & .860 & 2 & .430 & 5.149 & .007 \\
Computer $/ 11^{\text {th }}$ Grade No. of Students & 1066.667 & 1 & 1066.667 & 3.286 & .100 \\
Nursing $/ 11^{\text {th }}$ Grade No. of Sections & .006 & 2 & .003 & .130 & .878 \\
Nursing $/ 11^{\text {th }}$ Grade No. of Students & 144.500 & 1 & 144.500 & .000 & .000 \\
Trade $/ 11^{\text {th }}$ Grade No. of Sections & .015 & 2 & .008 & .867 & .422 \\
Industrial $/ 11^{\text {th }}$ Grade No. of Sections & .013 & 2 & .007 & 1.552 & .214 \\
Agricultural $/ 11^{\text {th }}$ Grade No. of Sections & .005 & 2 & .003 & .588 & .556 \\
Management $/ 11^{\text {th }}$ Grade No. of & .003 & 2 & .001 & .106 & .899 \\
Sections & & & & & .884 \\
Vocational $/ 11^{\text {th }}$ Grade No. of Sections & .061 & 2 & .030 & .415 \\
Vocational $/ 11^{\text {th }}$ Grade No. of Students & 161.333 & 1 & 161.333 & 15.613 & .058 \\
Beauty $/ 11^{\text {th }}$ Grade No. of Sections & .010 & 2 & .005 & .568 & .568 \\
\hline
\end{tabular}

However, differences of the capacity of quantity of Education Supply in three North Badia directorates were investigated using Scheffe Multiple Comparisons. Results in Table 12 indicated:

1. At Eleventh Grade number of sections in the Literature stream showed a difference in means of supply $(\mathrm{M}(\mathrm{I}-\mathrm{J})=-.204)$ between Central Mafraq \& Northeast Badia, where Central Mafraq shows lower performance than Northeast Badia; as well as, Central Mafraq \& Northwest Badia, (M(I-J) $=-.305)$, where Central Mafraq shows 1 performance than Northwest Badia.

2. At Eleventh Grade number of sections in the Computer stream showed a difference in means of supply $(\mathrm{M}(\mathrm{I}-\mathrm{J})=-.162)$ between Northwest Badia \& Northeast Badia, where Northwest Badia shows lower performance than Northeast Badia. 
Table 12. Scheffe multiple comparisons - eleventh grade stage students input/capacity of quantity of supply over North Badia directorates

\begin{tabular}{|c|c|c|c|c|c|c|c|}
\hline \multirow[t]{2}{*}{ Dependent Variable } & \multirow{2}{*}{$\begin{array}{l}\text { (I) North } \\
\text { Badia } \\
\text { Directorates }\end{array}$} & \multirow{2}{*}{$\begin{array}{l}\text { (J) North } \\
\text { Badia } \\
\text { Directorates }\end{array}$} & \multirow{2}{*}{$\begin{array}{l}\text { Mean } \\
\text { Difference } \\
\text { (I-J) }\end{array}$} & \multirow[t]{2}{*}{$\begin{array}{l}\text { Std. } \\
\text { Error }\end{array}$} & \multirow[t]{2}{*}{ Sig. } & \multicolumn{2}{|c|}{$\begin{array}{l}\text { 95\% Confidence } \\
\text { Interval }\end{array}$} \\
\hline & & & & & & $\begin{array}{l}\text { Lower } \\
\text { Bound }\end{array}$ & $\begin{array}{l}\text { Upper } \\
\text { Bound }\end{array}$ \\
\hline \multirow[t]{4}{*}{$\begin{array}{l}\text { Scientific } / 11^{\text {th }} \text { Grade } \\
\text { No. of Sections }\end{array}$} & $\begin{array}{l}\text { Central } \\
\text { Mafraq }\end{array}$ & $\begin{array}{l}\text { Northwest } \\
\text { Badia }\end{array}$ & -.096 & .079 & .473 & -.29 & .10 \\
\hline & & $\begin{array}{l}\text { Northeast } \\
\text { Badia }\end{array}$ & -.167 & .074 & .081 & -.35 & .02 \\
\hline & $\begin{array}{l}\text { Northwest } \\
\text { Badia }\end{array}$ & $\begin{array}{l}\text { Central } \\
\text { Mafraq }\end{array}$ & .096 & .079 & .473 & -.10 & .29 \\
\hline & & $\begin{array}{l}\text { Northeast } \\
\text { Badia }\end{array}$ & -.070 & .086 & .715 & -.28 & .14 \\
\hline \multirow[t]{4}{*}{$\begin{array}{l}\text { Scientific } / 11^{\text {th }} \text { Grade } \\
\text { No. of Students }\end{array}$} & $\begin{array}{l}\text { Central } \\
\text { Mafraq }\end{array}$ & $\begin{array}{l}\text { Northwest } \\
\text { Badia }\end{array}$ & 16.390 & 6.812 & .066 & -.86 & 33.64 \\
\hline & & $\begin{array}{l}\text { Northeast } \\
\text { Badia }\end{array}$ & 13.973 & 6.405 & .104 & -2.24 & 30.19 \\
\hline & $\begin{array}{l}\text { Northwest } \\
\text { Badia }\end{array}$ & $\begin{array}{l}\text { Central } \\
\text { Mafraq }\end{array}$ & -16.390 & 6.812 & .066 & -33.64 & .86 \\
\hline & & $\begin{array}{l}\text { Northeast } \\
\text { Badia }\end{array}$ & -2.417 & 6.140 & .926 & -17.96 & 13.13 \\
\hline \multirow{4}{*}{$\begin{array}{l}{\text { Literature } / 11^{\text {th }}}^{\text {Grade No. of }} \\
\underline{\text { Sections }}\end{array}$} & $\frac{\text { Central }}{\text { Mafraq }}$ & $\frac{\text { Northwest }}{\text { Badia }}$ & $\underline{-.305^{*}}$ & .083 & .001 & -.51 & -.10 \\
\hline & & $\begin{array}{l}\text { Northeast } \\
\text { Badia }\end{array}$ & $\underline{-.204^{*}}$ & .078 & .035 & -.40 & -.01 \\
\hline & $\begin{array}{l}\text { Northwest } \\
\text { Badia }\end{array}$ & $\begin{array}{l}\text { Central } \\
\text { Mafraq }\end{array}$ & $.305^{*}$ & .083 & .001 & .10 & .51 \\
\hline & & $\begin{array}{l}\text { Northeast } \\
\text { Badia }\end{array}$ & .101 & .091 & .540 & -.12 & .32 \\
\hline \multirow{4}{*}{$\begin{array}{l}\text { Literature/11 } \\
\text { Grade No. of } \\
\text { Students }\end{array}$} & $\begin{array}{l}\text { Central } \\
\text { Mafraq }\end{array}$ & $\begin{array}{l}\text { Northwest } \\
\text { Badia }\end{array}$ & 2.642 & 2.719 & .625 & -4.14 & 9.43 \\
\hline & & $\begin{array}{l}\text { Northeast } \\
\text { Badia }\end{array}$ & .857 & 2.739 & .952 & -5.98 & 7.69 \\
\hline & $\begin{array}{l}\text { Northwest } \\
\text { Badia }\end{array}$ & $\begin{array}{l}\text { Central } \\
\text { Mafraq }\end{array}$ & -2.642 & 2.719 & .625 & -9.43 & 4.14 \\
\hline & & $\begin{array}{l}\text { Northeast } \\
\text { Badia }\end{array}$ & -1.785 & 2.523 & .779 & -8.08 & 4.51 \\
\hline \multirow{4}{*}{$\begin{array}{l}\frac{\text { Computer } / 11^{\text {th }}}{\underline{\text { Grade No. of }}} \\
\underline{\text { Sections }}\end{array}$} & $\begin{array}{l}\text { Central } \\
\text { Mafraq }\end{array}$ & $\begin{array}{l}\text { Northwest } \\
\text { Badia }\end{array}$ & .057 & .048 & .491 & -.06 & .17 \\
\hline & & $\begin{array}{l}\text { Northeast } \\
\text { Badia }\end{array}$ & -.105 & .045 & .069 & -.22 & .01 \\
\hline & $\frac{\text { Northwest }}{\text { Badia }}$ & $\begin{array}{l}\text { Central } \\
\text { Mafraq }\end{array}$ & -.057 & .048 & .491 & -.17 & .06 \\
\hline & & $\begin{array}{l}\text { Northeast } \\
\text { Badia }\end{array}$ & $\underline{-.162^{*}}$ & .052 & .009 & -.29 & -.03 \\
\hline \multirow[t]{2}{*}{$\begin{array}{l}\text { Nursing/ } 11^{\text {th }} \text { Grade } \\
\text { No. of Sections }\end{array}$} & $\begin{array}{l}\text { Central } \\
\text { Mafraq }\end{array}$ & $\begin{array}{l}\text { Northwest } \\
\text { Badia }\end{array}$ & .001 & .024 & .999 & -.06 & .06 \\
\hline & & $\begin{array}{l}\text { Northeast } \\
\text { Badia }\end{array}$ & -.010 & .023 & .903 & -.07 & .05 \\
\hline
\end{tabular}




\begin{tabular}{|c|c|c|c|c|c|c|c|}
\hline & $\begin{array}{l}\text { Northwest } \\
\text { Badia }\end{array}$ & $\begin{array}{l}\text { Central } \\
\text { Mafraq }\end{array}$ & -.001 & .024 & .999 & -.06 & .06 \\
\hline & & $\begin{array}{l}\text { Northeast } \\
\text { Badia }\end{array}$ & -.012 & .027 & .910 & -.08 & .05 \\
\hline \multirow[t]{4}{*}{$\begin{array}{l}\text { Trade } / 11^{\text {th }} \text { Grade } \\
\text { No. of Sections }\end{array}$} & $\begin{array}{l}\text { Central } \\
\text { Mafraq }\end{array}$ & $\begin{array}{l}\text { Northwest } \\
\text { Badia }\end{array}$ & -.018 & .015 & .513 & -.06 & .02 \\
\hline & & $\begin{array}{l}\text { Northeast } \\
\text { Badia }\end{array}$ & -.015 & .015 & .600 & -.05 & .02 \\
\hline & $\begin{array}{l}\text { Northwest } \\
\text { Badia }\end{array}$ & $\begin{array}{l}\text { Central } \\
\text { Mafraq }\end{array}$ & .018 & .015 & .513 & -.02 & .06 \\
\hline & & $\begin{array}{l}\text { Northeast } \\
\text { Badia }\end{array}$ & .003 & .017 & .983 & -.04 & .04 \\
\hline \multirow[t]{4}{*}{$\begin{array}{l}\text { Industrial } / 11^{\text {th }} \text { Grade } \\
\text { No. of Sections }\end{array}$} & $\begin{array}{l}\text { Central } \\
\text { Mafraq }\end{array}$ & $\begin{array}{l}\text { Northwest } \\
\text { Badia }\end{array}$ & -.018 & .011 & .264 & -.04 & .01 \\
\hline & & $\begin{array}{l}\text { Northeast } \\
\text { Badia }\end{array}$ & .000 & .010 & 1.000 & -.03 & .03 \\
\hline & $\begin{array}{l}\text { Northwest } \\
\text { Badia }\end{array}$ & $\begin{array}{l}\text { Central } \\
\text { Mafraq }\end{array}$ & .018 & .011 & .264 & .00 & .04 \\
\hline & & $\begin{array}{l}\text { Northeast } \\
\text { Badia }\end{array}$ & .018 & .012 & .326 & -.01 & .05 \\
\hline \multirow{4}{*}{$\begin{array}{l}\text { Agricultural } / 11^{\text {th }} \\
\text { Grade No. of } \\
\text { Sections }\end{array}$} & $\begin{array}{l}\text { Central } \\
\text { Mafraq }\end{array}$ & $\begin{array}{l}\text { Northwest } \\
\text { Badia }\end{array}$ & .010 & .011 & .686 & -.02 & .04 \\
\hline & & $\begin{array}{l}\text { Northeast } \\
\text { Badia }\end{array}$ & .010 & .010 & .653 & -.02 & .03 \\
\hline & $\begin{array}{l}\text { Northwest } \\
\text { Badia }\end{array}$ & $\begin{array}{l}\text { Central } \\
\text { Mafraq }\end{array}$ & -.010 & .011 & .686 & -.04 & .02 \\
\hline & & $\begin{array}{l}\text { Northeast } \\
\text { Badia }\end{array}$ & .000 & .012 & 1.000 & -.03 & .03 \\
\hline \multirow{4}{*}{$\begin{array}{l}\text { Management } / 11^{\text {th }} \\
\text { Grade No. of } \\
\text { Sections }\end{array}$} & $\begin{array}{l}\text { Central } \\
\text { Mafraq }\end{array}$ & $\begin{array}{l}\text { Northwest } \\
\text { Badia }\end{array}$ & -.008 & .019 & .908 & -.05 & .04 \\
\hline & & $\begin{array}{l}\text { Northeast } \\
\text { Badia }\end{array}$ & -.005 & .018 & .959 & -.05 & .04 \\
\hline & $\begin{array}{l}\text { Northwest } \\
\text { Badia }\end{array}$ & $\begin{array}{l}\text { Central } \\
\text { Mafraq }\end{array}$ & .008 & .019 & .908 & -.04 & .05 \\
\hline & & $\begin{array}{l}\text { Northeast } \\
\text { Badia }\end{array}$ & .003 & .021 & .988 & -.05 & .05 \\
\hline \multirow{4}{*}{$\begin{array}{l}\text { Vocational } / 11^{\text {th }} \\
\text { Grade No. of } \\
\text { Sections }\end{array}$} & $\begin{array}{l}\text { Central } \\
\text { Mafraq }\end{array}$ & $\begin{array}{l}\text { Northwest } \\
\text { Badia }\end{array}$ & .029 & .031 & .649 & -.05 & .10 \\
\hline & & $\begin{array}{l}\text { Northeast } \\
\text { Badia }\end{array}$ & -.016 & .029 & .865 & -.09 & .06 \\
\hline & $\begin{array}{l}\text { Northwest } \\
\text { Badia }\end{array}$ & $\begin{array}{l}\text { Central } \\
\text { Mafraq }\end{array}$ & -.029 & .031 & .649 & -.10 & .05 \\
\hline & & $\begin{array}{l}\text { Northeast } \\
\text { Badia }\end{array}$ & -.044 & .033 & .421 & -.13 & .04 \\
\hline \multirow[t]{4}{*}{$\begin{array}{l}\text { Beauty/11 }{ }^{\text {th }} \text { Grade } \\
\text { No. of Sections }\end{array}$} & $\begin{array}{l}\text { Central } \\
\text { Mafraq }\end{array}$ & $\begin{array}{l}\text { Northwest } \\
\text { Badia }\end{array}$ & -.008 & .015 & .865 & -.05 & .03 \\
\hline & & $\begin{array}{l}\text { Northeast } \\
\text { Badia }\end{array}$ & .010 & .015 & .807 & -.03 & .05 \\
\hline & $\begin{array}{l}\text { Northwest } \\
\text { Badia }\end{array}$ & $\begin{array}{l}\text { Central } \\
\text { Mafraq }\end{array}$ & .008 & .015 & .865 & -.03 & .05 \\
\hline & & $\begin{array}{l}\text { Northeast } \\
\text { Badia }\end{array}$ & .018 & .017 & .571 & -.02 & .06 \\
\hline
\end{tabular}




\section{Quantitative Inputs of Twelfth Grade Stage Supply over North Badia Directorates}

The test of effect of directorates of North Badia Region over capacity of quantity of Education Supply at the Twelfth Grade stage using Anova Test of Variance, Table 13, indicated that numbers of students in the Scientific and Nursing streams are affected by geographical distribution. In addition, number of sections in the Literature and Computer streams is affected by geographical distribution.

Table 13. ANOVA - twelfth grade stage students input/capacity of quantity of supply over North Badia directorates

\begin{tabular}{|c|c|c|c|c|c|}
\hline Variable & Sum of Squares & df & Mean Square & $\mathrm{F}$ & Sig. \\
\hline Scientific $/ 12^{\text {th }}$ Grade No. of Sections & .783 & 2 & .391 & 1.615 & .201 \\
\hline$\underline{\text { Scientific } / 12^{\text {th }} \text { Grade No. of Students }}$ & 3040.047 & 2 & 1520.024 & 4.768 & .015 \\
\hline$\underline{\text { Literature }} / 12^{\text {th }}$ Grade No. of Sections & 5.234 & 2 & 2.617 & 11.074 & .000 \\
\hline Literature $/ 12^{\text {th }}$ Grade No. of Students & 253.777 & 2 & 126.888 & 1.447 & .242 \\
\hline$\underline{\text { Computer } / 12^{\text {th }} \text { Grade No. of Sections }}$ & 1.026 & 2 & .513 & 6.195 & .002 \\
\hline Computer $/ 12^{\text {th }}$ Grade No. of Students & 1001.042 & 1 & 1001.042 & 2.591 & .139 \\
\hline Nursing $/ 12^{\text {th }}$ Grade No. of Sections & .035 & 2 & .018 & .823 & .440 \\
\hline Nursing $/ 12^{\text {th }}$ Grade No. of Students & 160.167 & 1 & 160.167 & 320.333 & .036 \\
\hline Trade $/ 12^{\text {th }}$ Grade No. of Sections & .010 & 2 & .005 & 1.186 & .307 \\
\hline Industrial $/ 12^{\text {th }}$ Grade No. of Sections & .000 & 2 & .000 & . & . \\
\hline Agricultural $/ 12^{\text {th }}$ Grade No. of Sections & .005 & 2 & .003 & .588 & .556 \\
\hline Management $/ 12^{\text {th }}$ Grade No. of Sections & .021 & 2 & .010 & 1.188 & .307 \\
\hline Vocational $/ 12^{\text {th }}$ Grade No. of Sections & .061 & 2 & .031 & 1.014 & .364 \\
\hline Vocational $/ 12^{\text {th }}$ Grade No. of Students & 66.667 & 1 & 66.667 & . & . \\
\hline Beauty $/ 12^{\text {th }}$ Grade No. of Sections & .005 & 2 & .003 & .588 & .556 \\
\hline
\end{tabular}

However, differences of the capacity of quantity of Education Supply in three North Badia directorates were investigated using Scheffe Multiple Comparisons. Results in Table 14 indicated:

1) At Twelfth Grade number of students in the Scientific stream showed a difference in means of supply $(\mathrm{M}(\mathrm{I}-\mathrm{J})=23.286)$ between Central Mafraq \& Northwest Badia, where Central Mafraq shows higher performance than Northwest Badia. As well as, Central Mafraq \& Northeast Badia, $(M(I-J)=20.313)$, where Central Mafraq shows higher performance than Northeast Badia.

2) At Twelfth Grade number of sections in the Literature stream showed a difference in means of supply $(\mathrm{M}(\mathrm{I}-\mathrm{J})=-.354)$ between Central Mafraq \& Northwest Badia, where Northwest Badia shows higher performance than Central Mafraq. As well as, Central Mafraq \& Northeast Badia, (M(I-J) $=-.241)$, where Northeast Badia shows higher performance than Central Mafraq.

3) At Twelfth Grade number of sections in the Computer stream showed a difference in means of supply $(\mathrm{M}(\mathrm{I}-\mathrm{J})=-.138)$ between Central Mafraq \& Northeast Badia, where Central Mafraq shows lower performance than Northeast Badia; as well as, Northwest Badia \& Northeast Badia, $(\mathrm{M}(\mathrm{I}-\mathrm{J})=-.159)$, where Northeast Badia shows higher performance than Northwest Badia. 
Table 14. Scheffe multiple comparisons - twelfth grade stage students input/capacity of quantity of supply over North Badia directorates

\begin{tabular}{|c|c|c|c|c|c|c|c|}
\hline \multirow[t]{2}{*}{ Dependent Variable } & \multirow{2}{*}{$\begin{array}{l}\text { (I) North Badia } \\
\text { Directorates }\end{array}$} & \multirow{2}{*}{$\begin{array}{l}\text { (J) North Badia } \\
\text { Directorates }\end{array}$} & \multirow{2}{*}{$\begin{array}{l}\text { Mean } \\
\text { Difference } \\
(\mathrm{I}-\mathrm{J})\end{array}$} & \multirow{2}{*}{$\begin{array}{l}\text { Std. } \\
\text { Error }\end{array}$} & \multirow[t]{2}{*}{ Sig. } & \multicolumn{2}{|c|}{$95 \%$ Confidence Interval } \\
\hline & & & & & & $\begin{array}{l}\text { Lower } \\
\text { Bound }\end{array}$ & $\begin{array}{l}\text { Upper } \\
\text { Bound }\end{array}$ \\
\hline \multirow[t]{4}{*}{$\begin{array}{l}\text { Scientific/ } 12^{\text {th }} \text { Grade } \\
\text { No. of Sections }\end{array}$} & \multirow[t]{2}{*}{ Central Mafraq } & $\begin{array}{l}\text { Northwest } \\
\text { Badia }\end{array}$ & -.112 & .082 & .396 & -.31 & .09 \\
\hline & & Northeast Badia & -.122 & .077 & .284 & -.31 & .07 \\
\hline & \multirow{2}{*}{$\begin{array}{l}\text { Northwest } \\
\text { Badia }\end{array}$} & Central Mafraq & .112 & .082 & .396 & -.09 & .31 \\
\hline & & Northeast Badia & -.010 & .089 & .994 & -.23 & .21 \\
\hline \multirow[t]{4}{*}{$\frac{\text { Scientific/ } 12^{\text {th }} \text { Grade }}{\text { No. of Students }}$} & \multirow[t]{2}{*}{$\underline{\text { Central Mafraq }}$} & $\begin{array}{l}\text { Northwest } \\
\text { Badia }\end{array}$ & $\underline{23.286^{*}}$ & $\underline{7.913}$ & .021 & 3.06 & 43.51 \\
\hline & & Northeast Badia & $20.313^{*}$ & 7.731 & .043 & .55 & 40.08 \\
\hline & \multirow{2}{*}{$\begin{array}{l}\text { Northwest } \\
\text { Badia }\end{array}$} & Central Mafraq & $-23.286^{*}$ & 7.913 & .021 & -43.51 & -3.06 \\
\hline & & Northeast Badia & -2.973 & 6.534 & .902 & -19.68 & 13.73 \\
\hline \multirow[t]{4}{*}{$\begin{array}{l}\text { Literature } / 12^{\text {th }} \text { Grade } \\
\text { No. of Sections }\end{array}$} & \multirow[t]{2}{*}{$\underline{\text { Central Mafraq }}$} & $\frac{\text { Northwest }}{\text { Badia }}$ & $-.354^{*}$ & .080 & .000 & -.55 & -.16 \\
\hline & & Northeast Badia & $-.241^{*}$ & .076 & .007 & -.43 & -.05 \\
\hline & \multirow{2}{*}{$\begin{array}{l}\text { Northwest } \\
\text { Badia }\end{array}$} & Central Mafraq & $.354^{*}$ & .080 & .000 & .16 & .55 \\
\hline & & Northeast Badia & .112 & .088 & .441 & -.10 & .33 \\
\hline \multirow[t]{6}{*}{$\begin{array}{l}\text { Literature } / 12^{\text {th }} \text { Grade } \\
\text { No. of Students }\end{array}$} & \multirow[t]{2}{*}{ Central Mafraq } & $\begin{array}{l}\text { Northwest } \\
\text { Badia }\end{array}$ & 4.690 & 2.861 & .268 & -2.47 & 11.84 \\
\hline & & Northeast Badia & 1.926 & 2.900 & .803 & -5.33 & 9.18 \\
\hline & \multirow{2}{*}{$\begin{array}{l}\text { Northwest } \\
\text { Badia }\end{array}$} & Central Mafraq & -4.690 & 2.861 & .268 & -11.84 & 2.47 \\
\hline & & Northeast Badia & -2.764 & 2.505 & .547 & -9.03 & 3.50 \\
\hline & \multirow[t]{2}{*}{ Northeast Badia } & Central Mafraq & -1.926 & 2.900 & .803 & -9.18 & 5.33 \\
\hline & & $\begin{array}{l}\text { Northwest } \\
\text { Badia }\end{array}$ & 2.764 & 2.505 & .547 & -3.50 & 9.03 \\
\hline \multirow[t]{4}{*}{$\frac{\text { Computer } / 12^{\text {th }} \text { Grade }}{\text { No. of Sections }}$} & \multirow[t]{2}{*}{$\underline{\text { Central Mafraq }}$} & $\begin{array}{l}\text { Northwest } \\
\text { Badia }\end{array}$ & .020 & .048 & .914 & -.10 & .14 \\
\hline & & Northeast Badia & $-.138^{*}$ & .045 & .009 & -.25 & -.03 \\
\hline & \multirow{2}{*}{$\begin{array}{l}\text { Northwest } \\
\underline{\text { Badia }}\end{array}$} & Central Mafraq & -.020 & .048 & .914 & -.14 & .10 \\
\hline & & Northeast Badia & $-.159^{*}$ & .052 & .010 & -.29 & -.03 \\
\hline \multirow[t]{4}{*}{$\begin{array}{l}\text { Nursing/12 } 2^{\text {th }} \text { Grade } \\
\text { No. of Sections }\end{array}$} & \multirow[t]{2}{*}{ Central Mafraq } & $\begin{array}{l}\text { Northwest } \\
\text { Badia }\end{array}$ & .029 & .024 & .501 & -.03 & .09 \\
\hline & & Northeast Badia & .000 & .023 & .999 & -.06 & .06 \\
\hline & \multirow{2}{*}{$\begin{array}{l}\text { Northwest } \\
\text { Badia }\end{array}$} & Central Mafraq & -.029 & .024 & .501 & -.09 & .03 \\
\hline & & Northeast Badia & -.029 & .026 & .540 & -.09 & .04 \\
\hline \multirow[t]{4}{*}{$\begin{array}{l}\text { Trade } / 12^{\text {th }} \text { Grade No. } \\
\text { of Sections }\end{array}$} & \multirow[t]{2}{*}{ Central Mafraq } & $\begin{array}{l}\text { Northwest } \\
\text { Badia }\end{array}$ & .000 & .011 & 1.000 & -.03 & .03 \\
\hline & & Northeast Badia & -.015 & .010 & .361 & -.04 & .01 \\
\hline & Northwest & Central Mafraq & .000 & .011 & 1.000 & -.03 & .03 \\
\hline & Badia & Northeast Badia & -.015 & .012 & .468 & -.04 & .01 \\
\hline $\begin{array}{l}\text { Agricultural/ } 12^{\text {th }} \\
\text { Grade No. of Sections }\end{array}$ & Central Mafraq & $\begin{array}{l}\text { Northwest } \\
\text { Badia }\end{array}$ & .010 & .011 & .686 & -.02 & .04 \\
\hline & & Northeast Badia & .010 & .010 & .653 & -.02 & .03 \\
\hline & Northwest & Central Mafraq & -.010 & .011 & .686 & -.04 & .02 \\
\hline
\end{tabular}




\begin{tabular}{|c|c|c|c|c|c|c|c|}
\hline \multirow{5}{*}{$\begin{array}{l}\text { Management } / 12^{\text {th }} \\
\text { Grade No. of Sections }\end{array}$} & Badia & Northeast Badia & .000 & .012 & 1.000 & -.03 & .03 \\
\hline & Central Mafraq & $\begin{array}{l}\text { Northwest } \\
\text { Badia }\end{array}$ & .019 & .015 & .467 & -.02 & .06 \\
\hline & & Northeast Badia & .019 & .015 & .424 & -.02 & .05 \\
\hline & Northwest & Central Mafraq & -.019 & .015 & .467 & -.06 & .02 \\
\hline & Badia & Northeast Badia & .000 & .017 & 1.000 & -.04 & .04 \\
\hline \multirow[t]{4}{*}{$\begin{array}{l}\text { Vocational } / 12^{\text {th }} \text { Grade } \\
\text { No. of Sections }\end{array}$} & Central Mafraq & $\begin{array}{l}\text { Northwest } \\
\text { Badia }\end{array}$ & .019 & .029 & .803 & -.05 & .09 \\
\hline & & Northeast Badia & -.025 & .027 & .652 & -.09 & .04 \\
\hline & Northwest & Central Mafraq & -.019 & .029 & .803 & -.09 & .05 \\
\hline & Badia & Northeast Badia & -.044 & .031 & .374 & -.12 & .03 \\
\hline \multirow[t]{4}{*}{$\begin{array}{l}\text { Beauty } / 12^{\text {th }} \text { Grade No. } \\
\text { of Sections }\end{array}$} & Central Mafraq & $\begin{array}{l}\text { Northwest } \\
\text { Badia }\end{array}$ & .010 & .011 & .686 & -.02 & .04 \\
\hline & & Northeast Badia & .010 & .010 & .653 & -.02 & .03 \\
\hline & Northwest & Central Mafraq & -.010 & .011 & .686 & -.04 & .02 \\
\hline & Badia & Northeast Badia & .000 & .012 & 1.000 & -.03 & .03 \\
\hline
\end{tabular}

4.3.3 ANOVA Test - Effect of Overall Perceived Performance on Quantitative Inputs of Supply/Teachers over North Badia Directorates

Further analysis was carried out to investigate the effect of North Badia Region over capacity of quantity of Education Supply of teachers using anova test, as well as differences of the three North Badia directorates using Scheffe Multiple Comparisons as the following displays.

The test of effect of directorates of North Badia Region over capacity of quantity of Education Supply of Teachers using anova test (Table 15), indicated that numbers of Arts \& Athletics Teachers is affected by geographical distribution.

Table 15. ANOVA - teachers input/capacity of quantity of supply over North Badia directorates

\begin{tabular}{llllll}
\hline Variable & Sum of Squares & df & Mean Square & F & Sig. \\
\hline Religion Number of Teachers & .797 & 2 & .398 & .451 & .638 \\
Arabic Number of Teachers & .760 & 2 & .380 & .183 & .833 \\
English Number of Teachers & .586 & 2 & .293 & .215 & .806 \\
Culture Number of Teachers & .912 & 2 & .456 & 1.679 & .189 \\
Math Number of Teachers & 3.159 & 2 & 1.579 & 1.158 & .316 \\
Science Number of Teachers & 3.484 & 2 & 1.742 & 1.713 & .183 \\
Physics Number of Teachers & 1.784 & 2 & .892 & 2.487 & .085 \\
Chemistry Number of Teachers & 1.131 & 2 & .565 & 1.986 & .140 \\
Biology Number of Teachers & .175 & 2 & .088 & .318 & .728 \\
Geology Number of Teachers & .233 & 2 & .116 & .743 & .477 \\
Computer Number of Teachers & .223 & 2 & .112 & .137 & .872 \\
Geography Number of Teachers & .983 & 2 & .492 & 1.072 & .344 \\
History Number of Teachers & .257 & 2 & .129 & .377 & .686 \\
Arts Number of Teachers & 2.482 & 2 & 1.241 & 3.820 & .023 \\
Athleticss Number of Teachers & 3.862 & 2 & 1.931 & 4.780 & .009 \\
\hline Languages Number of Teachers & 12.256 & 2 & 6.128 & 2.681 & .071 \\
\hline
\end{tabular}

However, differences of the capacity of quantity of Education Supply in three North Badia Directorates were investigated using Scheffe Multiple Comparisons. Results in Table 16 indicated: 
1) Number of teachers in Arts showed a difference in means of supply $(\mathrm{M}(\mathrm{I}-\mathrm{J})=.261)$ between Central Mafraq \& Northwest Badia, where Central Mafraq shows higher performance than Northwest Badia.

2) Number of teachers in Athletics showed a difference in means of supply $(\mathrm{M}(\mathrm{I}-\mathrm{J})=-.306)$ between Central Mafraq \& Northeast Badia, where Northeast Badia shows higher performance than Central Mafraq.

Table 16. Scheffe multiple comparisons teachers input/capacity of quantity of supply over North Badia directorates

\begin{tabular}{|c|c|c|c|c|c|c|c|}
\hline \multirow[t]{2}{*}{ Dependent Variable } & \multirow{2}{*}{$\begin{array}{l}\text { (I) North Badia } \\
\text { Directorates }\end{array}$} & \multirow{2}{*}{$\begin{array}{l}\text { (J) North Badia } \\
\text { Directorates }\end{array}$} & \multirow{2}{*}{$\begin{array}{l}\text { Mean } \\
\text { Difference } \\
(\mathrm{I}-\mathrm{J})\end{array}$} & \multirow{2}{*}{$\begin{array}{l}\text { Std. } \\
\text { Error }\end{array}$} & \multirow[t]{2}{*}{ Sig. } & \multicolumn{2}{|c|}{ 95\% Confidence Interva } \\
\hline & & & & & & $\begin{array}{l}\text { Lower } \\
\text { Bound }\end{array}$ & $\begin{array}{l}\text { Upper } \\
\text { Bound }\end{array}$ \\
\hline \multirow[t]{4}{*}{$\begin{array}{l}\text { Religion Number of } \\
\text { Teachers }\end{array}$} & \multirow[t]{2}{*}{ Central Mafraq } & $\begin{array}{l}\text { Northwest } \\
\text { Badia }\end{array}$ & -.056 & .156 & .937 & -.44 & .33 \\
\hline & & Northeast Badia & -.139 & .146 & .638 & -.50 & .22 \\
\hline & \multirow{2}{*}{$\begin{array}{l}\text { Northwest } \\
\text { Badia }\end{array}$} & Central Mafraq & .056 & .156 & .937 & -.33 & .44 \\
\hline & & Northeast Badia & -.083 & .170 & .887 & -.50 & .34 \\
\hline \multirow[t]{4}{*}{$\begin{array}{l}\text { Arabic Number of } \\
\text { Teachers }\end{array}$} & \multirow[t]{2}{*}{ Central Mafraq } & $\begin{array}{l}\text { Northwest } \\
\text { Badia }\end{array}$ & -.031 & .238 & .992 & -.62 & .56 \\
\hline & & Northeast Badia & -.134 & .224 & .837 & -.69 & .42 \\
\hline & \multirow{2}{*}{$\begin{array}{l}\text { Northwest } \\
\text { Badia }\end{array}$} & Central Mafraq & .031 & .238 & .992 & -.56 & .62 \\
\hline & & Northeast Badia & -.103 & .260 & .924 & -.74 & .54 \\
\hline \multirow[t]{4}{*}{$\begin{array}{l}\text { English Number of } \\
\text { Teachers }\end{array}$} & \multirow[t]{2}{*}{ Central Mafraq } & $\begin{array}{l}\text { Northwest } \\
\text { Badia }\end{array}$ & .094 & .193 & .888 & -.38 & .57 \\
\hline & & Northeast Badia & -.041 & .182 & .974 & -.49 & .41 \\
\hline & \multirow{2}{*}{$\begin{array}{l}\text { Northwest } \\
\text { Badia }\end{array}$} & Central Mafraq & -.094 & .193 & .888 & -.57 & .38 \\
\hline & & Northeast Badia & -.136 & .210 & .813 & -.65 & .38 \\
\hline \multirow[t]{4}{*}{$\begin{array}{l}\text { Culture Number of } \\
\text { Teachers }\end{array}$} & \multirow[t]{2}{*}{ Central Mafraq } & $\begin{array}{l}\text { Northwest } \\
\text { Badia }\end{array}$ & -.042 & .086 & .890 & -.25 & .17 \\
\hline & & Northeast Badia & -.148 & .081 & .193 & -.35 & .05 \\
\hline & \multirow{2}{*}{$\begin{array}{l}\text { Northwest } \\
\text { Badia }\end{array}$} & Central Mafraq & .042 & .086 & .890 & -.17 & .25 \\
\hline & & Northeast Badia & -.106 & .094 & .530 & -.34 & .13 \\
\hline \multirow[t]{4}{*}{$\begin{array}{l}\text { Math Number of } \\
\text { Teachers }\end{array}$} & \multirow[t]{2}{*}{ Central Mafraq } & $\begin{array}{l}\text { Northwest } \\
\text { Badia }\end{array}$ & .026 & .193 & .991 & -.45 & .50 \\
\hline & & Northeast Badia & -.247 & .182 & .399 & -.69 & .20 \\
\hline & \multirow{2}{*}{$\begin{array}{l}\text { Northwest } \\
\text { Badia }\end{array}$} & Central Mafraq & -.026 & .193 & .991 & -.50 & .45 \\
\hline & & Northeast Badia & -.273 & .211 & .433 & -.79 & .25 \\
\hline \multirow[t]{4}{*}{$\begin{array}{l}\text { Science Number of } \\
\text { Teachers }\end{array}$} & \multirow[t]{2}{*}{ Central Mafraq } & $\begin{array}{l}\text { Northwest } \\
\text { Badia }\end{array}$ & .287 & .167 & .230 & -.12 & .70 \\
\hline & & Northeast Badia & .200 & .157 & .446 & -.19 & .59 \\
\hline & \multirow{2}{*}{$\begin{array}{l}\text { Northwest } \\
\text { Badia }\end{array}$} & Central Mafraq & -.287 & .167 & .230 & -.70 & .12 \\
\hline & & Northeast Badia & -.087 & .182 & .892 & -.54 & .36 \\
\hline \multirow[t]{4}{*}{$\begin{array}{l}\text { Physics Number of } \\
\text { Teachers }\end{array}$} & \multirow[t]{2}{*}{ Central Mafraq } & $\begin{array}{l}\text { Northwest } \\
\text { Badia }\end{array}$ & -.065 & .099 & .804 & -.31 & .18 \\
\hline & & Northeast Badia & -.207 & .093 & .087 & -.44 & .02 \\
\hline & \multirow{2}{*}{$\begin{array}{l}\text { Northwest } \\
\text { Badia }\end{array}$} & Central Mafraq & .065 & .099 & .804 & -.18 & .31 \\
\hline & & Northeast Badia & -.142 & .108 & .424 & -.41 & .12 \\
\hline \multirow[t]{2}{*}{$\begin{array}{l}\text { Chemistry Number of } \\
\text { Teachers }\end{array}$} & Central Mafraq & $\begin{array}{l}\text { Northwest } \\
\text { Badia }\end{array}$ & -.151 & .088 & .233 & -.37 & .07 \\
\hline & & Northeast Badia & -.131 & .083 & .289 & -.34 & .07 \\
\hline
\end{tabular}




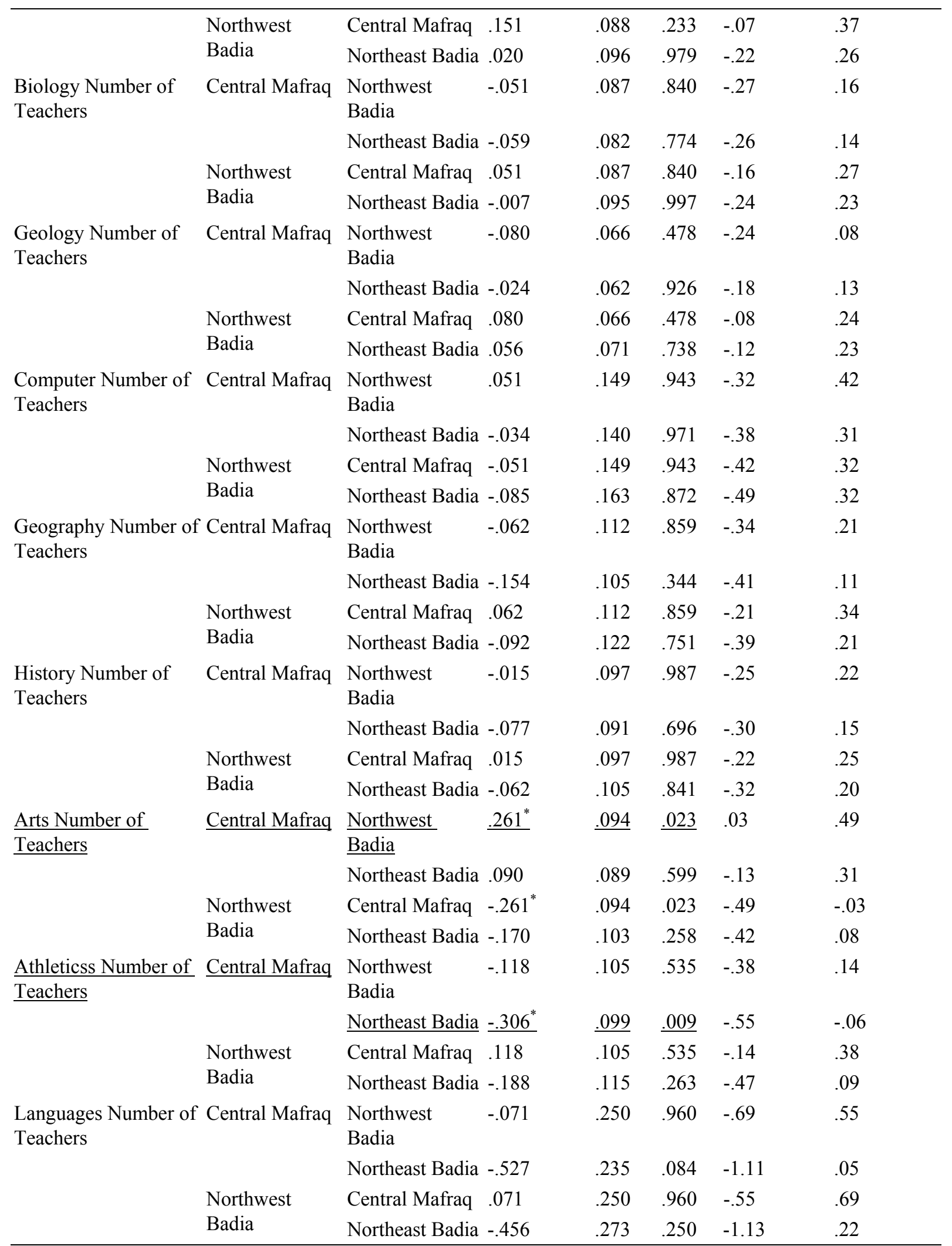

4.3.4 ANOVA Test - Effect of Overall Perceived Performance on Teaching-Organization \& Capacity of Quality of Supply \& Other Variables over North Badia Region

Further analysis was carried out to investigate the effect of Perceived overall performance over North Badia Region by Teaching-Organization \& Capacity of Quality of Education Supply \& Other Variables using anova test, as well as differences of the three North Badia directorates using Scheffe Multiple Comparisons as the 
following displays. Results in Table 17 showed a significant effect for School Education Levels and Teachers Attitude.

Table 17. ANOVA test - distribution of perceived students performance/overall learning efficacy over students gender, school's education levels, teaching-organization entity, and capacity of quality of supply $\&$ other variables over North Badia directorates

\begin{tabular}{llllll}
\hline Variables & Sum of Squares & Df & Mean Square & F & Sig. \\
\hline Students' Gender & .354 & 2 & .177 & .218 & .805 \\
School Education Level & 12.075 & 2 & 6.038 & 7.529 & .001 \\
Instructional & .117 & 2 & .058 & .386 & .680 \\
Structural & .558 & 2 & .279 & 1.093 & .337 \\
Staff Frustration & 4.846 & 2 & 2.423 & 2.882 & .058 \\
Positive Classroom Environment & 1.313 & 2 & .656 & 1.096 & .336 \\
Caring \& Support for Students & 1.285 & 2 & .643 & 1.495 & .226 \\
Formalization & 1.020 & 2 & .510 & 1.939 & .146 \\
Students Control & .037 & 2 & .019 & .095 & .910 \\
Perception of Existing Pedagogy & .318 & 2 & .159 & .422 & .656 \\
Directing Students Track & 3.012 & 2 & 1.506 & 1.564 & .211 \\
Obstacles of Ministry & 1.590 & 2 & .795 & 1.375 & .255 \\
Concentration & & & & & .029 \\
Students Attitude & .017 & 2 & .008 & .029 & .972 \\
Teachers Attitude & 1.859 & 2 & .929 & 3.179 & .044 \\
\hline Available School Services & .154 & 2 & .077 & .174 & .841 \\
\hline
\end{tabular}

However, differences of the capacity of School's education level, teaching-organization \& quality of Education Supply \& other variables in three North Badia directorates were investigated using Scheffe Multiple Comparisons. Results in Table 18 indicated:

1) School Education Level showed a difference in means $(\mathrm{M}(\mathrm{I}-\mathrm{J})=-.531)$ between Central Mafraq \& Northwest Badia, where Northwest Badia shows higher performance than Central Mafraq. In addition it showed a difference in means $(\mathrm{M}(\mathrm{I}-\mathrm{J})=-.378)$ between Central Mafraq \& Northeast Badia, where Northeast Badia shows higher performance than Central Mafraq.

2) Teachers Attitude showed a difference in means $(\mathrm{M}(\mathrm{I}-\mathrm{J})=.219)$ between Central Mafraq \& Northwest Badia, where Central Mafraq shows higher performance than Northwest Badia.

Table 18. Scheffe multiple comparisons - distribution of perceived students performance/overall learning efficacy, organizational entity, capacity of quality of supply \& other variables over North Badia directorates

\begin{tabular}{|c|c|c|c|c|c|c|c|}
\hline \multirow{2}{*}{$\begin{array}{l}\text { Dependent } \\
\text { Variable }\end{array}$} & \multirow{2}{*}{$\begin{array}{l}\text { (I) North Badia } \\
\text { Directorates }\end{array}$} & \multirow{2}{*}{$\begin{array}{l}(\mathrm{J}) \text { North Badia } \\
\text { Directorates }\end{array}$} & \multirow{2}{*}{$\begin{array}{l}\text { Mean } \\
\text { Difference } \\
(\mathrm{I}-\mathrm{J})\end{array}$} & \multirow{2}{*}{$\begin{array}{l}\text { Std. } \\
\text { Error }\end{array}$} & \multirow[t]{2}{*}{ Sig. } & \multicolumn{2}{|c|}{$95 \%$ Confidence Interval } \\
\hline & & & & & & $\begin{array}{l}\text { Lower } \\
\text { Bound }\end{array}$ & $\begin{array}{l}\text { Upper } \\
\text { Bound }\end{array}$ \\
\hline \multirow[t]{4}{*}{ Students' Gender } & Central Mafraq & $\begin{array}{l}\text { Northwest } \\
\text { Badia }\end{array}$ & .037 & .149 & .970 & -.33 & .40 \\
\hline & & Northeast Badia & .093 & .140 & .805 & -.25 & .44 \\
\hline & Northwest & Central Mafraq & -.037 & .149 & .970 & -.40 & .33 \\
\hline & Badia & Northeast Badia & .056 & .163 & .943 & -.35 & .46 \\
\hline
\end{tabular}




\begin{tabular}{|c|c|c|c|c|c|c|c|}
\hline$\underline{\text { School Education }}$ & Central Mafraq & Northwest & $\underline{-.531^{*}}$ & .148 & .002 & -.90 & -.17 \\
\hline \multirow[t]{4}{*}{$\underline{\text { Level }}$} & & $\underline{\text { Badia }}$ & & & & & \\
\hline & & $\underline{\text { Northeast Badia }}$ & $-.378^{*}$ & .139 & .027 & -.72 & -.03 \\
\hline & Northwest & Central Mafraq & $.531^{*}$ & .148 & .002 & .17 & .90 \\
\hline & Badia & Northeast Badia & .153 & .162 & .638 & -.24 & .55 \\
\hline \multirow[t]{4}{*}{ Instructional } & Central Mafraq & $\begin{array}{l}\text { Northwest } \\
\text { Badia }\end{array}$ & -.00714 & .06426 & .994 & -.1655 & .1512 \\
\hline & & Northeast Badia & -.05147 & .06045 & .696 & -.2004 & .0975 \\
\hline & Northwest & Central Mafraq & .00714 & .06426 & .994 & -.1512 & .1655 \\
\hline & Badia & Northeast Badia & -.04433 & .07008 & .819 & -.2170 & .1284 \\
\hline \multirow[t]{5}{*}{ Structural } & Central Mafraq & Northwest & .11270 & .08362 & .405 & -.0934 & .3188 \\
\hline & & Badia & & & & & \\
\hline & & Northeast Badia & .08364 & .07866 & .569 & -.1102 & .2775 \\
\hline & Northwest & Central Mafraq & -.11270 & .08362 & .405 & -.3188 & .0934 \\
\hline & Badia & Northeast Badia & -.02906 & .09119 & .950 & -.2538 & .1956 \\
\hline \multirow[t]{4}{*}{ Staff Frustration } & Central Mafraq & $\begin{array}{l}\text { Northwest } \\
\text { Badia }\end{array}$ & -.32202 & .15174 & .108 & -.6959 & .0519 \\
\hline & & Northeast Badia & -.26084 & .14274 & .191 & -.6126 & .0909 \\
\hline & Northwest & Central Mafraq & .32202 & .15174 & .108 & -.0519 & .6959 \\
\hline & Badia & Northeast Badia & .06119 & .16547 & .934 & -.3466 & .4689 \\
\hline Positive & Central Mafraq & Northwest & .13554 & .12808 & .572 & -.1801 & .4511 \\
\hline Classroom & & Badia & & & & & \\
\hline \multirow[t]{3}{*}{ Environment } & & Northeast Badia & .16301 & .12048 & .402 & -.1339 & .4599 \\
\hline & Northwest & Central Mafraq & -.13554 & .12808 & .572 & -.4511 & .1801 \\
\hline & Badia & Northeast Badia & .02746 & .13968 & .981 & -.3167 & .3716 \\
\hline \multirow[t]{4}{*}{$\begin{array}{l}\text { Caring \& Support } \\
\text { for Students }\end{array}$} & Central Mafraq & $\begin{array}{l}\text { Northwest } \\
\text { Badia }\end{array}$ & .12183 & .10849 & .533 & -.1455 & .3891 \\
\hline & & Northeast Badia & -.08231 & .10205 & .723 & -.3338 & .1692 \\
\hline & Northwest & Central Mafraq & -.12183 & .10849 & .533 & -.3891 & .1455 \\
\hline & Badia & Northeast Badia & -.20413 & .11831 & .228 & -.4957 & .0874 \\
\hline \multirow[t]{4}{*}{ Formalization } & Central Mafraq & $\begin{array}{l}\text { Northwest } \\
\text { Badia }\end{array}$ & .09782 & .08487 & .516 & -.1113 & .3069 \\
\hline & & Northeast Badia & -.08443 & .07983 & .572 & -.2811 & .1123 \\
\hline & Northwest & Central Mafraq & -.09782 & .08487 & .516 & -.3069 & .1113 \\
\hline & Badia & Northeast Badia & -.18225 & .09255 & .146 & -.4103 & .0458 \\
\hline Students Control & Central Mafraq & $\begin{array}{l}\text { Northwest } \\
\text { Badia }\end{array}$ & -.01528 & .07331 & .979 & -.1959 & .1654 \\
\hline
\end{tabular}




\begin{tabular}{|c|c|c|c|c|c|c|c|}
\hline & & Northeast Badia & -.02981 & .06896 & .911 & -.1997 & .1401 \\
\hline & Northwest & Central Mafraq & .01528 & .07331 & .979 & -.1654 & 1959 \\
\hline & Badia & Northeast Badia & -.01453 & .07994 & .984 & -.2115 & .1825 \\
\hline $\begin{array}{l}\text { Perception of } \\
\text { Existing }\end{array}$ & Central Mafraq & $\begin{array}{l}\text { Northwest } \\
\text { Badia }\end{array}$ & .08353 & .10159 & .714 & -.1668 & .3339 \\
\hline \multirow[t]{3}{*}{ Pedagogy } & & Northeast Badia & .06550 & .09556 & .791 & -.1700 & .3010 \\
\hline & Northwest & Central Mafraq & -.08353 & .10159 & .714 & -.3339 & .1668 \\
\hline & Badia & Northeast Badia & -.01803 & .11079 & .987 & -.2910 & .2549 \\
\hline \multirow{5}{*}{$\begin{array}{l}\text { Directing Students } \\
\text { Track }\end{array}$} & Central Mafraq & Northwest & .28512 & .16235 & .216 & -.1149 & .6852 \\
\hline & & Badia & & & & & \\
\hline & & Northeast Badia & .06926 & .15272 & .902 & -.3071 & .4456 \\
\hline & Northwest & Central Mafraq & -.28512 & .16235 & .216 & -.6852 & .1149 \\
\hline & Badia & Northeast Badia & -.21586 & .17705 & .477 & -.6521 & .2204 \\
\hline $\begin{array}{l}\text { Obstacles of } \\
\text { Ministry }\end{array}$ & Central Mafraq & $\begin{array}{l}\text { Northwest } \\
\text { Badia }\end{array}$ & -.10976 & .12583 & .684 & -.4198 & .2003 \\
\hline \multirow[t]{3}{*}{ Concentration } & & Northeast Badia & .11692 & .11837 & .615 & -.1747 & .4086 \\
\hline & Northwest & Central Mafraq & .10976 & .12583 & .684 & -.2003 & .4198 \\
\hline & Badia & Northeast Badia & .22668 & .13722 & .258 & -.1114 & .5648 \\
\hline \multirow[t]{4}{*}{ Students Attitude } & Central Mafraq & $\begin{array}{l}\text { Northwest } \\
\text { Badia }\end{array}$ & -.00625 & .08957 & .998 & -.2270 & .2145 \\
\hline & & Northeast Badia & .01581 & .08426 & .983 & -.1918 & .2234 \\
\hline & Northwest & Central Mafraq & .00625 & .08957 & .998 & -.2145 & .2270 \\
\hline & Badia & Northeast Badia & .02206 & .09768 & .975 & -.2186 & .2627 \\
\hline \multirow[t]{4}{*}{$\underline{\text { Teachers Attitude }}$} & $\underline{\text { Central Mafraq }}$ & $\frac{\text { Northwest }}{\underline{\text { Badia }}}$ & .219 & .08948 & .052 & -.0017 & .4393 \\
\hline & & Northeast Badia & .12425 & .08417 & .338 & -.0832 & .3317 \\
\hline & Northwest & Central Mafraq & -.21878 & .08948 & .052 & -.4393 & .0017 \\
\hline & Badia & Northeast Badia & -.09454 & .09758 & .626 & -.3350 & .1459 \\
\hline \multirow[t]{4}{*}{$\begin{array}{l}\text { Available School } \\
\text { Services }\end{array}$} & Central Mafraq & $\begin{array}{l}\text { Northwest } \\
\text { Badia }\end{array}$ & .05966 & .11014 & .864 & -.2117 & .3310 \\
\hline & & Northeast Badia & .04320 & .10361 & .917 & -.2121 & .2985 \\
\hline & Northwest & Central Mafraq & -.05966 & .11014 & .864 & -.3310 & .2117 \\
\hline & Badia & Northeast Badia & -.01646 & .12011 & .991 & -.3124 & .2795 \\
\hline
\end{tabular}

3) *. The mean difference is significant at the 0.05 level.

\section{Summary, Discussion \& Conclusions}

Capacity of quality of education Supply at the school level: perception of existing pedagogy has a slight tendency of approval; directing students to choose the right stream also received slight approval; and obstacles of Ministry of Education concentration has a tendency of agreement.

In terms of capacity of teaching-organizational entity of the supply, instructional capacity was assessed with a 
tendency of strong agreement; structural agreement was also with a tendency of strong agreement; staff frustration has a tendency of disproval; positive classroom environment has a slight tendency of approval; caring and support for students has a slight tendency of approval; formalization has a tendency of strong agreement; and students control has a strong agreement.

Additionally, students' attitude has a tendency of slight agreement; teachers' attitude has tendency of agreement; available school services has a slight agreement; and perceived students' performance has a tendency of slight agreement.

\subsection{Geographical Location over Student Performance}

Over all perceived performance was affected differently in the three directorates of North Badia; however, the highest perceived performance was in Central Mafraq and the least in Northeast Badia. In addition, geographical location was associated with number of students at Third, Fourth, Fifth, Sixth, Seventh, and Ninth Elementary grades. Further, geographical location was associated with number of students at Eleventh Grade Literature, Computer, Nursing stream, and number of sections at Eleventh grade Scientific, Literature, Computer, and Vocational streams. Finally, there was a strong and negative association with number of students at Twelfth grade scientific stream, and positive correlation of number of students with Nursing and Vocational streams, and a positive association with number of sections of Literature and Computer streams. Also, geographical location was only associated with number of Physics and Athletics teachers.

In terms of capacity of quantity of Education Supply at the Elementary level, results indicated that numbers of students at the elementary level from of $3^{\text {rd }}$ to $7^{\text {th }}$ grades affected overall performance with geographical distribution. However, performance showed differently in the three different directorates as follows:

1) At Third grade students numbers showed Central Mafraq have lower performance than Northeast Badia and Northwest Badia shows lower performance than Northeast Badia.

2) At Fourth grade students numbers showed that Central Mafraq have lower performance than Northeast Badia.

3) At Fifth grade students numbers showed that Central Mafraq have lower performance than Northeast Badia.

4) At Sixth grade, students numbers showed that Central Mafraq have lower performance than Northeast Badia.

5) At Seventh Grade, students numbers showed that Central Mafraq have lower performance than Northeast Badia, see Figure 103.

In terms of capacity of quantity of Education Supply at the Eleventh Grade level, results indicated that numbers of students in the scientific stream and number of sections in the Literature and Computer streams affected overall performance with geographical distribution. However, performance showed differently in the three different directorates as follows:

1) At Eleventh Grade number of sections in the Literature stream showed that Central Mafraq have higher performance than Northeast Badia and Central Mafraq have lower performance than Northwest Badia,

2) At Eleventh Grade number of sections in the Computer stream showed that Northwest Badia has lower performance than Northeast Badia.

In terms of capacity of quantity of Education Supply at the Twelfth Grade level, results indicated that numbers of students in the Scientific and Nursing streams and number of sections in the Literature and Computer streams are affected by overall performance with geographical distribution. However, performance showed differently in the three different directorates as follows:

1) At Twelfth Grade number of students in the scientific stream showed that Central Mafraq has higher performance than Northwest Badia and Central Mafraq have higher performance than Northeast Badia.

2) At Twelfth Grade number of sections in the Literature stream showed that Northwest Badia has higher performance than Central Mafraq and Northeast Badia have higher performance than Central Mafraq.

3) At Twelfth Grade number of sections in the Computer stream showed that Central Mafraq has lower performance than Northeast Badia and Northeast Badia have higher performance than Northwest Badia.

In terms of capacity of quantity of Supply of teacher's, results indicated that numbers of Arts \& Athletics Teachers are affected by overall performance with geographical distribution. However, performance showed differently in the three different directorates as follows: 
1) Number of teachers in Arts showed that Central Mafraq have higher performance than Northwest Badia.

2) Number of teachers in Athletics showed that Northeast Badia have higher performance than Central Mafraq.

In terms of Teaching-Organization, Capacity of Quality of Education Supply, and other variables effect, results indicated that school education level and teacher attitude is affected by overall performance with geographical distribution. However, performance showed differently in the three different directorates as follows, which supports Evans, Kliewer, \& Martin (1991), Berglund \& Lindvall (1986), and Cohen, Evans, Stokols \& Krantz (1986):

1) School Education Level showed that Northwest Badia has higher performance than Central Mafraq and Northeast Badia have higher performance than Central Mafraq.

2) Teachers Attitude showed that Central Mafraq have higher performance than Northwest Badia.

\subsection{Recommendations - Vision and Solutions}

The study suggests that continuing gap between education and development outcomes may lead policy makers to consider alternative paths of educational development in the future. There should be a strategy formulation to restructure higher education inputs in Mafraq Governorate to match outputs in order to supply the local market demands. In order to provide a strategy to restructure higher education inputs in Mafraq Governorate so as to match outputs that satisfy the local market needs and to supply the demand for such needs. Major issues that should be considered by education policy makers include:

1) Restructure of inputs of education in the Northeast Badia Region.

2) Emphasis of joining schools together, as it seems number of students as well as section are vital for output and more so than number of teachers. Many schools are suffering, especially in the Northeast Badia Region, from small number of students in geographically dispersed villages. It is healthier to increase numbers of students to a range of 20-30 per section for completion among students.

3) Number of teachers and their major seem to be sufficient and more importantly are their attitude. This suggests working more on enhancing the teachers' attitude, as their qualifications seem sufficient but they lack inspiration and incentives and it seems to be a worthwhile issue of investment by policy maker of higher education.

4) Physical infrastructure that supports students' activity seems vital and affects student's performance positively. Therefore, it is worth to invest in sports and arts facilities, and the like.

Further obstacles' solutions that hinder the local community include the following:

1) Suggestion for Cultural obstacles: activation of parents councils in order to share cultural issues and taboos about education and work; activation of students council for awareness of vocational studies; and launching summer school for students in order to keep them disciplined and interested.

2) Suggestion for Social obstacles include: activation of parents and local community councils to increase bridging and communication and responsibility towards education; emphasizing teachers mission; providing trained counselors to solve students social problems; establishing open-door policy with the community; intensifying teachers' roles and social status; and enhancing team spirit.

3) Suggestion for Financial obstacles include: launching activities that generate money so as to enhance facilities and services at local schools; encourage donations and financial support by the local community and civic institutions; decrease school fees; honoring donors by assigning their names to school facilities; decreasing centralization and offering local management some freedom to enhance school budget; and increasing incentives for teachers and school budget by the Ministry of Education.

4) Suggestion for Managerial obstacles include: allowing new managements approach; activating mangers role and authority; decentralizing decisions; activating punishment law; providing management incentives; bridging communication with managers and exchanging experience with other schools; and increasing capacity of municipals by intensifying training workshops.

5) Suggestion for Training obstacles include: providing teachers with training before their first teaching; providing continuous and intensive training and awareness about teaching skills, responsibilities, and classroom environment; encouraging effective training and participation; providing and increasing chances of training; evaluating training content; training students with speaking disabilities at local schools; 
launching summer training and workshops to save time; and training senior teachers about new methods and pedagogies.

6) Suggestion for Technical obstacles include: supporting managers with technical team to get their job done; providing serious supervisors in the region, one supervisor for each subject; establishing extensive technical training and supervision by the Ministry of Education.

7) Suggestion for Logistic obstacles include: increasing and enhancing infrastructure and services for students, teachers, and management; distributing services equally among schools; implementing safety measures at the main street in front of the schools.

\subsection{Implication}

1) Policy makers: should not be mainly concerned about the inputs of schooling (finance, curriculum, and student allocation), but should also pay attentions about the internal process of the school, such as instructional approaches, school structure, etc.

2) School administrators: the school environment may be related to the contextual factors of the schools, such as age, size, experience of the teachers, etc., which is not under the control of the school administrators, but they have the authority to plan and implement suitable policies which can reduce the negative effects of the school contextual factors.

3) Education department: since the principal is in a key role in the creation of a good school environment, which would be beneficial to the learning of the students and the success of the teachers, it implies that selection and training of principal should be given prominent attention by the policy makers and Education Department.

4) Training programs: because the principal has multiple roles, he/she is an educational leader, a structural leader, a human relationship leader, a political leader, and a symbolic leader; it suggests that training programs for the principal should include the five components.

\subsection{Limitations of the Research Study}

The research aperwork was long and even when released was not enough to convince the local municipals to collaborate with the extensive data related to teachers and students inputs (especially scores of students in all subjects and at all level). Further, teachers at the interviewed schools offered no time to work with or help the research team in extracting this data. In addition at the central exam office of the Ministry this data, which was supposed to be upload to EduWave, were not accessible or available. In terms of questionnaire, it was long, for future studies components of the research will be separated in different parcels and phases. Finally, the timing of the research was towards the end of the academic year; many schools where dropped out from the study because they were on vacation.

\section{Acknowledgement}

Funding for this work was provided by Deanship of Scientific Research, German-Jordanian University, Amman, Jordan, in 2008.

\section{References}

Al-Oun, S. (1997). Livestock Marketing in the Jordanian Badia. Ph.D. Thesis, Durham University, UK.

Aptekar, L. (1983). Mexican-American high school students' perception of school. Adolescence, 18, 345-357.

Assaad, R. (1994). The effects of public sector hiring and compensation policies on the Egyptian labor market. Working Paper 9517, Economic Research Forum for the Arab Countries, Iran \& Turkey, Cairo, Egypt.

Barker, R., \& Gump, P. (1964). Big school, small school: high school size and student behavior. Stanford, CA: Stanford University Press.

Bates, J. (1993). Portrait of a successful rural alternative school. Rural Educator, 14, $20-24$.

Berlin, B \& Cienkus, R. (1989). Size: The Ultimate Educational Issue? Education and Urban Society, 21, 228-231. http://dx.doi.org/10.1177/0013124589021002010

Bolman, L., \& Deal, T. (1991). Leadership and management effectiveness: a multi-frame, multi-sector analysis. Human Resource Management, 30, 509-534. http://dx.doi.org/10.1002/hrm.3930300406

Burke, A. (1987). Making a big school smaller: the school-within-a-school arrangement for middle level schools. Orting, WA: Orting Middle School, (ED 303 890). 
Berglund, B., \& Lindvall, T. (1986). Sensory reactions to sick buildings. Environment International, 12, 147-159. http://dx.doi.org/10.1016/0160-4120(86)90025-5

Brooks, C., \& Rebeta, J. (1991). College classroom ecology: the relation of sex of student to classroom performance and seating preference. Environment and Behavior, 23, 305-313. http://dx.doi.org/10.1177/0013916591233003

Bush, T. (1986). Theories of educational management. London: Harper and Row.

Campbell, W., Cotterell. J., Robinson, N., \& Sadler, D. (1981). Effects of school size upon some aspects of personality. The Journal of Educational Administration, 19, 201-231. http://dx.doi.org/10.1108/eb009848

Carlson, C. (1992). The first step of marketing a college or university. AMA Symposium on the Marketing of Higher Education, 5-13.

Cawelti, G. (1993). Restructuring large high schools to personalize learning for all. ERS Spectrum, 11, 17-21.

Cheng, Y. (1993). Principal's leadership as a critical factor for school performance: evidence from multi-levels of primary schools. Paper presented at The International Congress for School Effectiveness and Improvement, Sweden, Norrkoping, January, 1993.

Cohen, S., Evans, G., Stokols, D., \& Krantz, D. (1986). Behavior, health, and environmental stress. New York: Plenum.

Coleman, M. (1994). Marketing and external relations. In T. Bush\& J. West-Bumham (Eds.), The Principles of educational management (pp.361-386). Essex: Longman.

Conway, T., Mackay, S., \& Yorke, D. (1994). Strategic planning in higher education: Who are the customers. International Journal of Education Management, 8, 29-36. http://dx.doi.org/10.1108/09513549410069202

Cotton, K. (1996). School size, school climate, and student performance. Close-Up \#20. Retrieved August, 2011 from http://www.nwrel.org/scpd/sirs/10/c020.html

Department of Statistics. (2001). Amman, Hashemite Kingdom of Jordan.

Department of Statistics. (2002). Amman, Hashemite Kingdom of Jordan.

Department of Statistics. (2004). Amman, Hashemite Kingdom of Jordan.

Docquier, F., \& Marfouk, A. (2004). International migration by educational attainment, 1990-2000. In C. Ozden \& Schiff (Ed.), International migration, remittances and the brain drain. Washington, DC: World Bank and Palgrave Macmillan.

Duderstadt, J. (1999). New roles for the 21st-century university. Issues of Science and Technology. Retrieved August, 2011 from http://www.nap.edu/issues/16.2/duderstadt.html

Duke, D., \& Perry, C. (1978). Can alternative schools succeed where benjamin spock, spiro agnew, and b. f. skinner have failed? Adolescence, 13, 375-392.

Eberts, R., Kehoe, E., \& Stone, J. (1982). The effect of school size on student outcomes. Final Report. Eugene, OR: Center for Educational Policy and Management, University of Oregon, (ED 245 382).

Eichenstein, R. (1994). Project Achieve, Part I: Qualitative Findings 1993-94. Brooklyn, NY: Office of Educational Research, New York City Board of Education (ED 379 388).

Evans, G., Kliewer, W., \& Martin, J. (1991). The role of the physical environment in the health and well-being of children. In H. E. Schroeder (Ed.), New Directions in Health Psychology Assessment (pp. 127-157). New York: Hemisphere.

Fawzy, S. (2002). Investment policies and unemployment in Egypt. Presentation at conference on Employment and Unemployment in Egypt, sponsored by the Egyptian Center for Economic Studies, Cairo, Egypt, January 13-14, 2002.

Fetler, M. (1989). School dropout rates, academic performance, size, and poverty: correlates of educational reform. Educational Evaluation and Policy Analysis, 11, 109-116.

Fisk, R., \& Allen, J. (1993). Applying marketing techniques to achieve the strategic objectives of educational institutions: A case study. AMA Symposium for the Marketing of Higher Education, pp70-77.

Fowler, W. (1995). School size and student outcomes. Advances in Educational Productivity, 5, 3-26.

Fowler, W. (1992). What do we know about school size? What should we know? Paper presented to the 
American Educational Research Association Annual Meeting, San Francisco, CA. Available from the Office of Educational Research and Improvement, National Center for Educational Statistics, U.S. Department of Education, Washington, D.C.

Fowler, W., \& Walberg, H. (1991). School size, characteristics, and outcomes. Educational Evaluation and Policy Analysis, 13, 189-202.

Galal, A. (2008). The road not traveled: education reform in the Middle East and North Africa. Published January 2008 by World Bank.

Galal, A. (2002). The paradox of education and unemployment in Egypt. The Egyptian Center for Economic Studies (ECES).

Galal, A., \& Fawzy, S. (2001). Egypt's export puzzle, policy viewpoint 9. The Egyptian Center for Economic Studies, Cairo, Egypt.

Garbarino, J. (1980). Some thoughts on school size and its effects on adolescent development. Journal of Youth and Adolescence, 9, 19-31. http://dx.doi.org/10.1007/BF02088377

Girgis, M. (2002). Would nationals and Asians replace Arab workers in the GCC? Paper presented at the Fourth Mediterranean Development Forum entitled Progress for All, Visions for the Future, Amman. October 6, 2002.

Gottfredson, D. (1985). School size and school disorder. Baltimore, MD: Center for Social Organization of Schools. Johns Hopkins University (ED 261 456).

Grabe, M. (1981). School size and the importance of school activities. Adolescence, 16, 21-31.

Gray, L. (1991). Marketing education. Bristol: Open University Press.

Gregory, T. (1992). Small is too big: achieving a critical anti-mass in the high school. In Source Book on School and District Size, Cost, and Quality. Minneapolis, MN: Minnesota University, Hubert H. Hum-phrey Institute of Public Affairs; Oak Brook, IL: North Central Regional Educational Laboratory, 1-31 (ED 361 159).

Gregory, T., \& Smith, G. (1987). The case for small high schools. In High Schools as Communities: The Small School Reconsidered. Bloomington, IN: Phi Delta Kappa, 68-85 (ED 278 518).

Gump, P. (1987). School and classroom environments. In D. Stokols and I. Altman (Eds.). Handbook of Environmental Psychology (pp. 698-701). New York: Wiley.

Haller, E., Monk, D., \& Tien, L. (1993). Small schools and higher-order thinking skills. Journal of Research in Rural Education, 9, 66-73.

Howley, C. (1994). The academic effectiveness of small-scale schooling (an update). ERIC Digest. Charleston, WV: Clearinghouse on Rural Education and Small Schools, (ED 372 897).

Howley, C. (1995). The Matthew principle: a west Virginia replication? Education Policy Analysis Archives, 3(18), 1-25. Retrieved August, 2011 from http://www.seamonkey.ed.asu.edu/epaa/v13n18.html

Howley, C. (1996). Literature review. In Sizing up Schooling: A West Virginia Analysis and Critique. Unpublished Doctoral Dissertation, West Virginia University, Morgan-town, WV.

Johnson, S. (1990). Teachers at work: achieving success in our schools. New York: Basic Books.

Keller, G. (1983). Academic strategy. Baltimore, MD: The Johns Hopkins University Press.

Koneya, M. (1976). Location and interaction in the row and column seating arrangements, Environment and Behavior, 8, 265-282. http://dx.doi.org/10.1177/001391657682005

Kotler, P., \& Fox, K. (1995). Strategic marketing for educational institutions (2nd ed.). New Jersey: Prentice Hall.

Lackney, J. (1999). The Relationship between environmental quality of school facilities and student performance. Congressional Briefing to the U.S. House of Representatives Committee on Science Sponsored by the Environmental Energy Study Institute (EESI). Retrieved August, 2011 from http://www.schoolstudio.engr.wisc.edu/energysmartschools.html

Laclau, E., \& Mouffe, C. (1985). Hegemony and socialist strategy: Towards a radical democratic politics. London: Verso.

Lewin, K. (1943). Defining the field at a given time. Psychological Review, 50, $292-310$. 
http://dx.doi.org/10.1037/h0062738

Lin, L. (1999). Linking marketing and TQM in higher educational institutions. The Hague: Dutch Quality Schools.

Lowrie, A., \& Willmott, H. (2006). Marketing higher education: the promotion of relevance and the relevance of promotion. Social Epistemology, 20, 221-240. http://dx.doi.org/10.1080/02691720600879806

Mayron, L., Ott, J., Nations, R., \& Mayron, E. (1974). Light, radiation and academic behavior. Academic Therapy, 40, 33-47.

McGanney, M., Mei, D., \& Rosenblum, J. (1989). Ninth grade houses: the program and its impact in New York city public high schools. Paper presented at the Annual Meeting of the American Educational Research Association, San Francisco, CA, (ED 306 284).

Ming, T., \& Cheong, C. (1995). School environment and student performance: a multi-level analysis. Educational Research Journal, 10, 5-21.

Ming, T. (1994). School environment as related to performance of teachers and students. Master of Philosophy in Education Thesis, The Chinese University of Hong Kong Graduate School - Division Of Education.

Murphy, P., \& McGarrity, R. (1978). Marketing universities: a survey of student recruiting activities. College and University, 249-261.

MoHE (Ministry of Higher Education). (2007). National strategy for higher education and research, years 2007-2012. Ministry of Higher Education, Amman, Jordan.

Panizza, U. (2001). Macroeconomic policies in egypt: an interpretation of the past and options for the future, Working Paper 61. The Egyptian Center for Economic Studies. Cairo, Egypt.

Pittman, R., \& Haughwout, P. (1987). Influence of high school size on dropout rate. Educational Evaluation and Policy Analysis, 9, 337-343.

Radwan, S. (1998). Towards full employment: Egypt into the 21st century. Distinguished Lecture Series No. 10, The Egyptian Center for Economic Studies, Cairo, Egypt.

Raze, N. (1985). Instructional implications for small schools: a review of the literature. Redwood City, CA: San Mateo County Office of Education, SMERC Information Center, (ED 272 347).

Robertson, P. (1995). Reinventing the high school: the coalition campus school project in New York City. Paper presented at the Annual Meeting of the American Educational Research Association, San Francisco, CA.

Robinson, A., \& Long, G. (1987). Substance v trappings in the marketing of non-advanced further education. Journal of Further and Higher Education, 12, 42-51. http://dx.doi.org/10.1080/0309877880120103

Rogers, R. (1987). Is bigger better? Fact or fad concerning school district organization. ERS Spectrum, 5, 36-39.

Rutter, R. (1988). Effects of school as a community. Madison, WI: National Center on Effective Secondary Schools, (ED 313 470).

Schoggen, P., \& Schoggen, M. (1988). Student voluntary participation and high school size. Journal of Educational Research, 81, 288-293.

Scott, S. (1999). The academic as service provider: Is the customer 'always. Journal of Higher Education Policy \& Management, 21, 193-203. http://dx.doi.org/10.1080/1360080990210206

Sergiovanni, T. (1984). Leadership and Excellence in Schooling. Educational Leadership, February, 4-3.

Smith, D., \& DeYoung, A. (1988). Big school vs. small school: conceptual, empirical, and political perspectives on the re-emerging debate. Journal of Rural and Small Schools, 2-11.

Stockard, J., \& Mayberry, M. (1992). Resources and School and Classroom Size. Chapter 3 in Effective educational environments. Newbury Park, CA: Corwin Press, Inc., 40-58.

Stolp, S. (1995). Every school a community: the academic value of strong social bonds among staff and students. OSSC Bulletin 39/1: entire issue.

Summers, A., \& Wolfe, B. (1977). Do schools make a difference? American Economic Review, 67, 639-652.

Tam, W., \& Cheng, Y. (1995). School environment and student performance: a multi-level analysis. Paper presented at the International Congress for School Effectiveness and Improvement, Leeuwarden, The Netherlands, January, 1995. 
The World Bank. (2011). The road not traveled: education reform in the Middle East and North Africa, Chapter 1. Retrieved August, 2011 from www.worldbank.org

Toenjes, L. (1989). Dropout rates in texas school districts: influences of school size and ethnic group. Austin, TX: Texas Center for Educational Research, (ED 324 783).

Totusek, P \& Staton-Spicer, A. (1982). Classroom seating preferences as a function of student personality. Journal of Experimental Education, 505, 159-163.

Valiulis, A. (2003). Transit economy market challenge and university respond. European Journal of Engineering Education, 28, 453-464. http://dx.doi.org/10.1080/0304379032000101827

Valiulis, A., \& Zavadskas, E. (1999). Collaboration between academia and the economy under the conditions of an economy in transition. Proceedings of the 3rd Baltic North Badia Regions Seminar on Engineering Education (Chalmers University of Technology, Go"teborg, Sweden), pp. 162-165.

Walberg, H. (1992). On local control: is bigger better? In Source Book on School and District Size, Cost, and Quality. Minneapolis, MN: Minnesota University, Hubert H. Humphrey Institute of Public Affairs; Oak Brook, IL: North Central Regional Educational Laboratory, 118-134 (ED 361 164).

Wallace, J. (1999). The case for student as customer. Quarterly Progress, 32, 36-41.

Weinstein, C. S. (1985). Seating arrangements in the classroom. International Encyclopedia of Education. New York: Pergamon.

Wonders, T., \& Gyuere, J. (1991). Opportunistic marketing in higher education. In T. J. Hayes (Eds.), New strategies in higher education marketing (pp. 1-16). New York: The Haworth Press.

World Bank. (2004). World development report 2004: making services work for poor people by World Bank. Oxford University Press, World Bank. 